\title{
Isolation, X-ray Crystal Structure and Theoretical Calculations of the New Compound 8-Epicordatin and Identification of others Terpenes and Steroids from the Bark and Leaves of Croton palanostigma Klotzsch
}

\author{
Davi S. B. Brasil, ${ }^{a, b}$ Adolfo H. Müller, ${ }^{*, a, c}$ Gisele M. S. P. Guilhon, ${ }^{a}$ Cláudio N. Alves, ${ }^{a}$ \\ Gabriel Peris, ${ }^{d}$ Rosa Llusar ${ }^{d}$ and Vicent Moliner ${ }^{d}$
}

${ }^{a}$ Instituto de Ciências Exatas e Naturais, Universidade Federal do Pará, Av. Augusto Corrêa, 01, 66075-900 Belém-PA, Brazil

${ }^{b}$ Faculdade de Engenharia Química, Instituto de Tecnologia, Universidade Federal do Pará, Av. Augusto Corrêa, 01, 66075-900 Belém-PA, Brazil

${ }^{c}$ Centro Universitário do Estado do Pará, Av Nazaré, 630, 66035-170 Belém-PA, Brazil

${ }^{d}$ Departament de Química Física i Analítica, Universitat Jaume I, 12071, Castellón, Spain

Estudos fitoquímicos com as cascas do caule e com as folhas de Croton palanostigma Klotzsch (Euphorbiaceae) levaram ao isolamento do novo diterpeno clerodânico 8-epicordatina (2), além de éster metílico do ácido 12-oxohardwickiico (3), aparisthmano, cordatina (1), ácido ent-trachiloban18-óico, óxido de ent-13-epimanoila, óxido de ent-3-oxo-13-epimanoila, óxido de ent-3ß-hidroxi13-epimanoila, sitosterol, estigmasterol, estigmastan-3-ona, 6 $\beta$-hidroxiestigmast-4-en-3-ona, 6 $\beta$-hidroxiestigmasta-4,22-dien-3-ona, estigmast-4-en-3-ona, estigmasta-4,22-dien-3-ona, ácido 3-O-acetilaleuritolico, $11 \alpha$-hidroxiurs-12-en-3-ona, $\alpha$-amirenona, 24-metilenocicloartenona e lupenona. Estas substâncias foram isoladas através de procedimentos fitoquímicos usuais e suas estruturas foram deduzidas por estudos espectroscópicos, incluindo experimentos em 2D. Adicionalmente, a estrutura cristalina de 8-epicordatina (2) foi determinada por difração de raios-X. Cálculos teóricos de RMN ao nível B3PW91/DGDZVP foram usados para confirmação dos assinalamentos dos deslocamentos químicos dos hidrogênios H-7 $\alpha$ e H-7 $\beta$ de 8-epicordatina.

Phytochemical studies of the bark and leaves of Croton palanostigma Klotzsch (Euphorbiaceae) led to the isolation of a new clerodane diterpene, 8-epicordatin (2), in addition to 12-oxohardwickiic acid methyl ester (3), aparisthman, cordatin (1), ent-trachyloban-18-oic acid, ent-13-epimanoyl oxide, ent-3-oxo-13-epimanoyl oxide, ent-3 $\beta$-hydroxy-13-epimanoyl oxide, sitosterol, stigmasterol, stigmastan-3-one, $6 \beta$-hydroxystigmast-4-en-3-one, 6 $\beta$-hydroxystigmasta-4,22-dien-3-one, stigmast-4-en-3-one, stigmasta-4,22-dien-3-one, 3- $O$-acetylaleuritolic acid, $11 \alpha$-hydroxyurs-12en-3-one, $\alpha$-amyrenone, 24-methylenecycloartenone and lupenone. These compounds were isolated using typical phytochemical procedures and the structures were deduced from spectroscopic studies, including 2D NMR experiments. In addition, the crystalline structure of 8-epicordatin (2) was determined by X-ray diffraction. NMR theoretical calculations at the B3PW91/DGDZVP level were used to confirm the assignment of the chemical shifts of the $\mathrm{H}-7 \alpha$ and $\mathrm{H}-7 \beta$ hydrogens of 8-epicordatin.

Keywords: Croton palanostigma Klotzsch, terpenes, steroids, NMR DFT calculations, X-ray crystallography

\section{Introduction}

Croton palanostigma Klotzsch (Euphorbiaceae) is a medium-sized tree native to the Northern Brazilian

\footnotetext{
*e-mail: muller@ufpa.br, muller@cesupa.br
}

coastal region. Phytochemical studies of the bark of C. palanostigma under the erroneous identification of Aparisthmium cordatum ${ }^{1}$ yielded two furan diterpenes with a clerodane skeleton, namely, aparisthman ${ }^{2}$ and cordatin (1). ${ }^{3}$ These compounds showed anti-ulcer activity similar to that of cimetidine $\left(\right.$ Tagamet $^{\circledR}$ ), a compound used for the 
treatment of peptic ulcers. ${ }^{4,5}$ This species, together with various Croton spp., is known to produce a red viscous sap called dragon's blood. The sap of C. palanostigma is reported to have various pharmacological and physiological actions. ${ }^{6}$ Phytochemical studies of dragon's blood obtained from Croton spp. led to the isolation of the alkaloid taspine, ${ }^{7}$ the dihydrobenzofuran lignans 3',4-O-dimethylcedrusin ${ }^{8}$ and 4-O-methylcedrusin, ${ }^{9}$ and proanthocyanidins. ${ }^{10}$

The principal mechanism of the anti-ulcerogenic effect of cordatin (1) remains unknown. It seems to be related to an anti-secretory property, but the involvement of a mucosal defensive mechanism should not be ignored. ${ }^{5}$ Other anti-ulcerogenic drugs, such as the proton pump inhibitors omeprazole, lansoprazole and pantoprazole, exist as pro-drugs that need activation for interaction with gastric $\mathrm{H}^{+}, \mathrm{K}^{+}$-ATPase.${ }^{11}$ Protonation of these compounds results in extensive molecular rearrangement followed by the formation of a positively charged sulfenamide species that has a low permeability coefficient across membranes and reacts covalently with free sulfhydryl group(s) on the extracellular surface of $\mathrm{H}^{+}, \mathrm{K}^{+}$-ATPase. ${ }^{12}$ The sulfonamide forms a disulfide that covalently modifies the enzyme's extracellular domain and inhibits it with a stoichiometry of $\sim 2$ molecules of drug per subunit of $\mathrm{H}^{+}, \mathrm{K}^{+}$-ATPase. ${ }^{11}$

In the present work, a new phytochemical study of $C$. palanostigma was undertaken. The dichloromethane extract of the bark resulted in the new compound 8-epicordatin (2) (Figure 1). The hexane extract of the bark yielded 12-oxohardwickiic acid methyl ester (3), together with other six diterpenoids, seven steroids and one triterpenoid. The hexane extract of the leaves yielded four triterpenoids. This study demonstrates the use of theoretical calculations in determining geometric parameters, chemical shifts and NMR coupling constants. The molecular electrostatic potential (MEP) was also calculated to define the most probable sites of interaction of $\mathbf{1}$ and $\mathbf{2}$ with $\mathrm{H}^{+}$ions in gastric fluid.

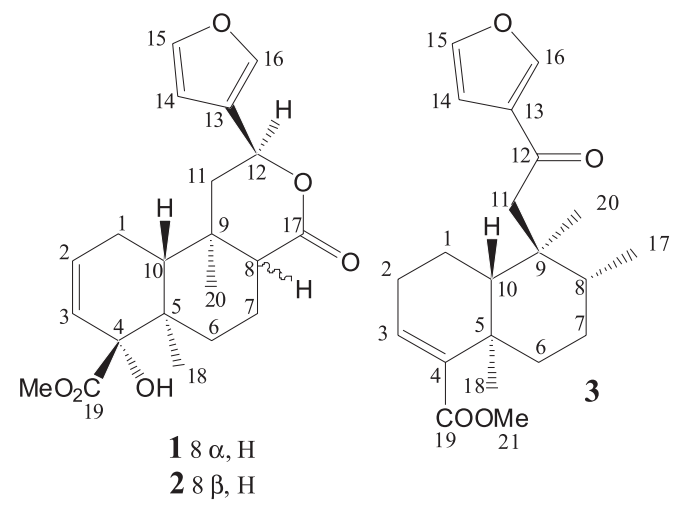

Figure 1. Structures of 1, 2 and 3.

\section{Results and Discussion}

The structures of the isolated compounds were deduced mainly from ${ }^{1} \mathrm{H}$ and ${ }^{13} \mathrm{C}$ NMR spectroscopic data at 300 and $75.4 \mathrm{MHz}$, respectively, with the aid of ${ }^{1} \mathrm{H},{ }^{1} \mathrm{H}-\mathrm{COSY}$, ${ }^{13} \mathrm{C},{ }^{1} \mathrm{H}-\mathrm{COSY}-{ }^{1} J(\mathrm{CH})$ and ${ }^{13} \mathrm{C},{ }^{1} \mathrm{H}-\mathrm{COSY}^{2 ; 3} \mathrm{~J}(\mathrm{CH})$ spectra. DEPT pulse sequences were used to determine the hydrogenation pattern of the carbons.

12-Oxohardwickiic acid methyl ester (3) was isolated as an oil. Its molecular formula is $\mathrm{C}_{21} \mathrm{H}_{28} \mathrm{O}_{4}$ (EIMS). Its IR spectrum is consistent with the presence of two conjugated carbonyl groups corresponding to peaks at 1668 (ketone adjacent to a furan ring) and $1714 \mathrm{~cm}^{-1}$ (ester adjacent to a double bond) and a furan ring $\left(3135,1509\right.$ and $\left.872 \mathrm{~cm}^{-1}\right) .^{13}$ Table 1 shows the ${ }^{1} \mathrm{H}$ and ${ }^{13} \mathrm{C}$ NMR spectroscopic data for 3 ; these data are in complete agreement with those reported in the literature for $\mathbf{3}$, which was obtained by oxidation of 12-hydroxyhardwickiic acid methyl ester, isolated from a hexane extract of the roots of Croton sonderianus. ${ }^{14}$ This compound (3) was isolated for the first time as a natural product from Croton polyandrous. ${ }^{15}$

The new natural product 8-epicordatin (2) was isolated as crystals. Its IR spectrum is consistent with the presence of an $\mathrm{O}-\mathrm{H}$ group $\left(3540 \mathrm{~cm}^{-1}\right)$, two carbonyl groups corresponding to peaks at 1704 ( $\delta$-lactone) and $1733 \mathrm{~cm}^{-1}$ (methyl ester) and a furan ring $\left(3100,1503\right.$ and $\left.873 \mathrm{~cm}^{-1}\right){ }^{13}$ Its molecular formula is $\mathrm{C}_{21} \mathrm{H}_{26} \mathrm{O}_{6}$ (HRMS). This compound was identified by comparison of its NMR data (Table 1) with those reported in the literature for cordatin $(\mathbf{1})^{3}$ crotobrasilin $\mathrm{A}^{16}$ and epi-cordatin. ${ }^{17}$ In addition, the NOESY data are similar to those reported in the literature used to propose the relative configurations at asymmetric centers for crotobrasilin $\mathrm{A}^{16}$ (Figure 2). Therefore, the new natural product 8-epicordatin (2) is the non-acetylated form of crotobrasilin A. ${ }^{16}$ Finally, the structure of 8-epicordatin (2) was also confirmed by X-ray diffraction. The ORTEP representation for the molecular labeling in the X-ray structure of $\mathbf{2}$ is shown in Figure 3. The most relevant X-ray

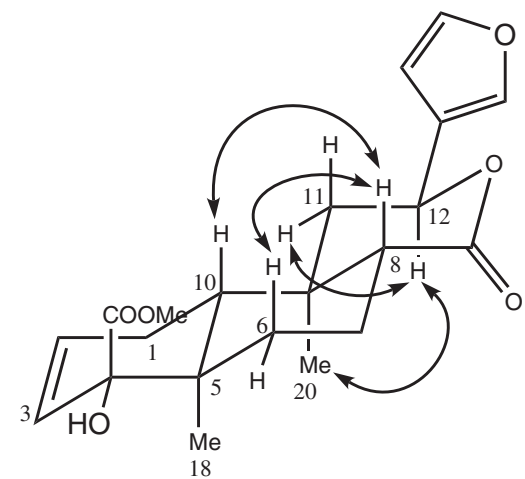

Figure 2. Significant NOESY correlations of 2. 


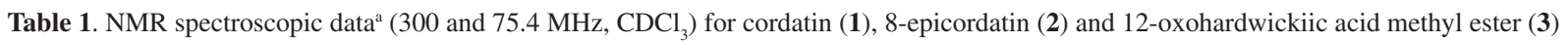

\begin{tabular}{|c|c|c|c|c|c|c|}
\hline \multirow[t]{2}{*}{ Position } & \multicolumn{2}{|c|}{ Cordatin (1) } & \multicolumn{2}{|c|}{ 8-Epicordatin (2) } & \multicolumn{2}{|c|}{ 12-Oxohardwickiic acid methyl ester (3) } \\
\hline & $\delta_{\mathrm{C}}$, mult. & $\delta_{\mathrm{H}}(\mathrm{J}$ in $\mathrm{Hz})$ & $\delta_{\mathrm{C}}$, mult. & $\delta_{\mathrm{H}}(\mathrm{J}$ in $\mathrm{Hz})$ & $\delta_{\mathrm{C}}$, mult. & $\delta_{\mathrm{H}}(\mathrm{J}$ in $\mathrm{Hz})$ \\
\hline 1 & $23.1, \mathrm{CH}_{2}$ & $2.02, \mathrm{~m}$ & $22.9, \mathrm{CH}_{2}$ & $2.10, \mathrm{~m}$ & $18.9, \mathrm{CH}_{2}$ & $\begin{array}{c}\alpha, 1.52, \operatorname{ddd}(1.3,7.5,13.5) \\
\beta, 1.76, \mathrm{~m}\end{array}$ \\
\hline 2 & $130.0, \mathrm{CH}$ & $\begin{array}{c}5.93, \text { ddd } \\
(2.7,4.6,10.1)\end{array}$ & $130.0, \mathrm{CH}$ & $\begin{array}{c}5.95, \text { ddd } \\
(2.9,4.6,10.0)\end{array}$ & 27.0, $\mathrm{CH}_{2}$ & $\begin{array}{c}\alpha, 2.15, \mathrm{~m} \\
\beta, 2.07, \mathrm{ddd} \\
(3.3,7.5,11.4)\end{array}$ \\
\hline 3 & $128.5, \mathrm{CH}$ & $\begin{array}{c}5.31, \mathrm{dt} \\
(2.3,10.1)\end{array}$ & 128.7, $\mathrm{CH}$ & $\begin{array}{c}5.36, \mathrm{ddd} \\
(1.8,2.5,10.0)\end{array}$ & $137.3, \mathrm{CH}$ & 6.56, dd $(3.3,4.5)$ \\
\hline 4 & 80.7, ${ }_{9} \mathrm{C}$ & & $81.2,{ }_{q} \mathrm{C}$ & & $141.9,{ }_{q} \mathrm{C}$ & \\
\hline 5 & 40.6, ${ }_{9} \mathrm{C}$ & & $40.5,{ }_{\mathrm{q}} \mathrm{C}$ & & $37.9,{ }_{\mathrm{q}} \mathrm{C}$ & \\
\hline 6 & $28.4, \mathrm{CH}_{2}$ & $\begin{array}{c}\alpha, 1.54, \mathrm{dt}(3.6,13.4) \\
\beta, 1.36, \mathrm{~m}\end{array}$ & $33.2, \mathrm{CH}_{2}$ & $\begin{array}{l}\alpha, 1.86, \mathrm{dt}(2.7,13.3) \\
\beta, 0.91, \mathrm{td}(3.0,13.3)\end{array}$ & $35.3, \mathrm{CH}_{2}$ & $\begin{array}{c}\alpha, 2.23, \mathrm{dt}(3.0,12.7) \\
\beta, 1.12, \mathrm{~m}\end{array}$ \\
\hline 7 & $17.7, \mathrm{CH}_{2}$ & $\begin{array}{c}\alpha, 1.78, \mathrm{~m} \\
\beta, 2.10, \mathrm{dq}(3.6,15.2)\end{array}$ & $18.1, \mathrm{CH}_{2}$ & $\mathrm{a}, 1.60, \mathrm{~m} \mathrm{~b}, 2.10, \mathrm{~m}$ & $27.4, \mathrm{CH}_{2}$ & $1.40, \mathrm{~m}$ \\
\hline 8 & $44.9, \mathrm{CH}$ & $2.48, \mathrm{dd}(1.9,3.6)$ & $51.4, \mathrm{CH}$ & $2.07, \mathrm{~m}$ & $37.3, \mathrm{CH}$ & $1.86, \mathrm{~m}$ \\
\hline 9 & $35.3,{ }_{9} \mathrm{C}$ & & $36.4,{ }_{9} \mathrm{C}$ & & 42.4, ${ }_{9} \mathrm{C}$ & \\
\hline 10 & 44.7, $\mathrm{CH}$ & $2.29, \mathrm{dd}(5.6,10.4)$ & 44.7, $\mathrm{CH}$ & $2.33, \mathrm{dd}(5.2,11.0)$ & $47.1, \mathrm{CH}$ & $1.70, \mathrm{dd}(1.3,13.5)$ \\
\hline 11 & $48.9, \mathrm{CH}_{2}$ & $\begin{array}{c}\alpha, 2.00, \mathrm{dd}(1.8,14.1) \\
\beta, 1.78, \mathrm{~m}\end{array}$ & 44.4, $\mathrm{CH}_{2}$ & $\begin{array}{c}\alpha, 2.29, \mathrm{dd}(5.4,13.6) \\
\beta, 1.67, \mathrm{dd}(11.7,13.6)\end{array}$ & 47.6, $\mathrm{CH}_{2}$ & $\begin{array}{l}\text { a, 2.70, d (14.8) } \\
\text { b, 2.77, d (14.8) }\end{array}$ \\
\hline 12 & $69.8, \mathrm{CH}$ & $5.24 \mathrm{br}, \mathrm{d}(11.0)$ & 71.9, $\mathrm{CH}$ & $5.48, \mathrm{dd}(5.4,11.7)$ & 194.9, ${ }_{q} \mathrm{C}$ & \\
\hline 13 & $123.9,{ }_{\mathrm{q}} \mathrm{C}$ & & $125.8,{ }_{q} \mathrm{C}$ & & 129.6, ${ }_{q} \mathrm{C}$ & \\
\hline 14 & $108.5, \mathrm{CH}$ & $6.42, \mathrm{dd}(0.9,1.9)$ & $108.5, \mathrm{CH}$ & $6.41, \mathrm{dd}(0.9,1.9)$ & $108.9, \mathrm{CH}$ & $6.73, \mathrm{dd}(0.8,1.9)$ \\
\hline 15 & 143.6, CH & $7.41, \mathrm{t}(1.9)$ & $143.7, \mathrm{CH}$ & $7.41, \mathrm{t}(1.9)$ & 144.1, CH & $7.41, \mathrm{dd}(1.4,1.9)$ \\
\hline 16 & $139.6, \mathrm{CH}$ & $7.47 \mathrm{br}, \mathrm{s}$ & 139.3, $\mathrm{CH}$ & 7.44, m & $146.7, \mathrm{CH}$ & $7.99, \mathrm{dd}(0.8,1.4)$ \\
\hline 17 & $173.8,{ }_{\mathrm{q}} \mathrm{C}$ & & 171.9, ${ }_{\mathrm{q}} \mathrm{C}$ & & $16.6, \mathrm{CH}_{3}$ & $0.90, \mathrm{~d}(6.8)$ \\
\hline 18 & $14.8, \mathrm{CH}_{3}$ & $1.10, \mathrm{~s}$ & $15.2, \mathrm{CH}_{3}$ & $1.12, \mathrm{~s}$ & $20.6, \mathrm{CH}_{3}$ & $1.26, \mathrm{~s}$ \\
\hline 19 & 175.9, ${ }_{\mathrm{q}} \mathrm{C}$ & & 175.5, ${ }_{q} \mathrm{C}$ & & 167.7, ${ }_{q} \mathrm{C}$ & \\
\hline 20 & $24.4, \mathrm{CH}_{3}$ & $1.32, \mathrm{~s}$ & $15.4, \mathrm{CH}_{3}$ & $1.17, \mathrm{~s}$ & 17.6, $\mathrm{CH}_{3}$ & $0.84, \mathrm{~s}$ \\
\hline 21 & $53.4, \mathrm{CH}_{3}$ & $3.78, \mathrm{~s}$ & $53.2, \mathrm{CH}_{3}$ & $3.81, \mathrm{~s}$ & $51.0, \mathrm{CH}_{3}$ & $3.66, \mathrm{~s}$ \\
\hline
\end{tabular}

${ }^{a 1} \mathrm{H}$ NMR referenced to $\mathrm{CHCl}_{3}$ at $\delta 7.26 \mathrm{ppm} ;{ }^{1} \mathrm{H},{ }^{1} \mathrm{H}$-COSY spectra were used to determine spin-spin interactions. ${ }^{13} \mathrm{C} \mathrm{NMR} \mathrm{referenced} \mathrm{to} \mathrm{CHCl}_{3}$ at $\delta 77.00 \mathrm{ppm}$. All assignments were confirmed by ${ }^{1} \mathrm{H},{ }^{1} \mathrm{H}-\mathrm{COSY}{ }^{13} \mathrm{C},{ }^{1} \mathrm{H}-\mathrm{COSY}-{ }^{-1} \mathrm{~J}_{\mathrm{CH}}$ and ${ }^{13} \mathrm{C},{ }^{1} \mathrm{H}-\mathrm{COSY}-2 ; 3 J_{\mathrm{CH}}$ experiments.

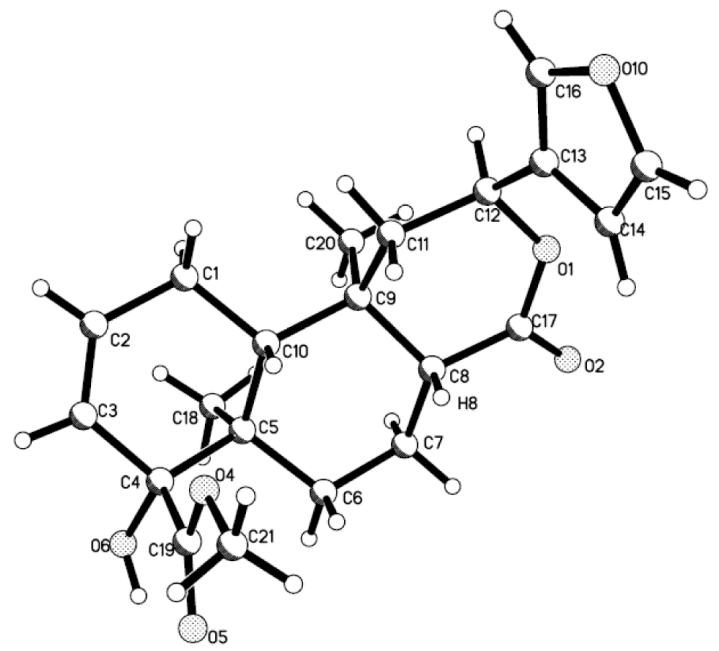

Figure 3. ORTEP representation of 2. and theoretical structural parameters for 2 are shown in Tables 2 and 3; complete data for the X-ray structure are shown in the supplementary material.

The configurations of the asymmetrical centers of aparisthman and cordatin (1) were determined by comparison of their NMR spectroscopic data with those obtained for authentic samples. Detailed NMR data for $\mathbf{1}$ are presented in Table 1.

The known compounds were identified by comparison of their spectroscopic data with those reported in the literature. The ${ }^{13} \mathrm{C}$ NMR spectral signals of ent-trachyloban18-oic acid at $\delta 16.2$ (Me-19) and 14.9 (Me-20) excluded the possible epimer ent-trachyloban-19-oic acid ${ }^{18}$ [ $\delta 28.8$ (Me-18) and 12.4 (Me-20)]. Furthermore, the configuration of ent-8 $\alpha, 13 S$ to ent-3-oxo-13-epimanoyl oxide was confirmed by comparison of its optical rotation, 
Table 2. Crystallographic data for 2

\begin{tabular}{|c|c|}
\hline Empirical formula & $\mathrm{C}_{21} \mathrm{H}_{26} \mathrm{O}_{6}$ \\
\hline Molecular weight & 374.42 \\
\hline Temperature & $273(2) \mathrm{K}$ \\
\hline Wavelength & $0.71073 \AA$ \\
\hline Crystal system & Tetragonal \\
\hline Space group & $\mathrm{P} 4(1) 2(1) 2$ \\
\hline \multirow[t]{3}{*}{ Unit cell dimensions } & $a=11.9617(5) \AA, \alpha=90^{\circ}$ \\
\hline & $b=11.9617(5) \AA, \beta=90^{\circ}$ \\
\hline & $c=26.1728(15) \AA, \gamma=90^{\circ}$ \\
\hline Volume & $3744.9(3) \AA^{3}$ \\
\hline $\mathrm{Z}$ & 8 \\
\hline Density (calculated) & $1.328 \mathrm{~g} / \mathrm{m}^{3}$ \\
\hline Absorption coefficient & $0.097 \mathrm{~mm}^{-1}$ \\
\hline $\mathrm{F}(000)$ & 1600 \\
\hline Crystal size & $0.50 \times 0.36 \times 0.29 \mathrm{~mm}^{3}$ \\
\hline$\theta$ range for data collection & $1.87-26.37^{\circ}$ \\
\hline Index ranges & $-10 \leq \mathrm{h} \leq 10,0 \leq \mathrm{k} \leq 14,0 \leq \mathrm{l} \leq 32$ \\
\hline Reflections collected & 3832 \\
\hline Independent reflections & $3832[R(\mathrm{int})=0.0000]$ \\
\hline Completeness to $\theta=26.37^{\circ}$ & $100.0 \%$ \\
\hline Absorption correction & Semi-empirical from equivalents \\
\hline Max. and min. transmission & 0.9725 and 0.9532 \\
\hline Refinement method & Full-matrix least-squares on $F^{2}$ \\
\hline Data/restraints/parameters & $3832 / 0 / 249$ \\
\hline Goodness-of-fit of $F^{2}$ & 1.015 \\
\hline Final $R$ indices $[\mathrm{I}>2 \operatorname{sigma}(\mathrm{I})]$ & $\mathrm{R} 1=0.0576, \mathrm{wR} 2=0.1489$ \\
\hline$R$ indices (all data) & $\mathrm{R} 1=0.0915, \mathrm{wR} 2=0.1775$ \\
\hline Extinction coefficient & $0.0063(13)$ \\
\hline Largest diff. peak and hole & 0.243 and $-0.179{\mathrm{e} \AA^{-3}}^{-3}$ \\
\hline
\end{tabular}

$[\alpha]_{\mathrm{D}}^{25}-50.9^{\circ}\left(\mathrm{CHCl}_{3}, c 0.11\right)$ and spectroscopic data to those reported in the literature. ${ }^{19}$ The same configuration was proposed for ent-13-epimanoyl oxide and ent-3 $\beta$-hydroxy13-epimanoyl oxide.

The atomic distances, angles and torsion angles for both X-ray and B3LYP/6-31G $(d, p)$ optimized structures of 2 presented in Table 3 are common for this type of compound. The hydroxyl group $\mathrm{O} 6-\mathrm{H}$ is involved in an intramolecular hydrogen bond with O5 at $2.128 \AA$ (1.941 in calculations).

The crystallographic parameters for $\mathbf{2}$ were compared with data from the literature for $\mathbf{1},{ }^{1,3}$ revealing similar structural parameters in the case of a trans relationship between the methyl group (C-20) attached to C-9 and the hydrogen borne by $\mathrm{C}-10$, and the same type of relationship between the methyl group $(\mathrm{C}-18)$ attached to $\mathrm{C}-5$ and the carbonyl carbon (C-19) linked to $\mathrm{C}-4$. The cis relationship existing between the hydrogen on $\mathrm{C}-8$ and the methyl group (C-20) located at C-9 in $\mathbf{1}^{1,3}$ is not present in $\mathbf{2}$. In this case, a trans relationship is observed. These results demonstrate that $\mathbf{2}$ has a trans-clerodane skeleton with a chair conformation for ring $\mathrm{B}$ and half-chair conformations for rings $\mathrm{A}$ and $\mathrm{C}$ due to the location of the double bond between $\mathrm{C}-2$ and $\mathrm{C}-3$ and the ester group at C-17.

Table 3. Experimental and theoretical structural parameters for 2

\begin{tabular}{|c|c|c|}
\hline Structural parameters & Experimental $^{\mathrm{a}}$ & B3LYP/6-31G $(d, p)$ \\
\hline \multicolumn{3}{|l|}{ Bond distance $(\AA)$} \\
\hline C4-C19 & $1.533(4)$ & 1.553 \\
\hline C19-O5 & $1.205(3)$ & 1.218 \\
\hline C19-O4 & $1.317(4)$ & 1.338 \\
\hline $\mathrm{O} 4-\mathrm{C} 21$ & $1.437(3)$ & 1.443 \\
\hline $\mathrm{C} 4-\mathrm{O} 6$ & $1.432(4)$ & 1.421 \\
\hline C9-C20 & $1.536(4)$ & 1.546 \\
\hline C5-C18 & $1.549(4)$ & 1.548 \\
\hline $\mathrm{C} 17-\mathrm{O} 2$ & $1.214(5)$ & 1.208 \\
\hline $\mathrm{C} 12-\mathrm{C} 13$ & $1.494(6)$ & 1.498 \\
\hline \multicolumn{3}{|l|}{ Bond angle $\left(^{\circ}\right)$} \\
\hline C4-C19-O5 & $123.6(3)$ & 121.7 \\
\hline C4-C19-O4 & $113.4(2)$ & 115.2 \\
\hline O5-C19-O4 & $123.0(3)$ & 123.1 \\
\hline C19-O4-C21 & $117.5(2)$ & 115.5 \\
\hline $\mathrm{C} 3-\mathrm{C} 4-\mathrm{O} 6$ & $106.5(3)$ & 108.1 \\
\hline C10-C9-C20 & $114.2(2)$ & 113.9 \\
\hline $\mathrm{C} 8-\mathrm{C} 17-\mathrm{O} 2$ & $123.5(6)$ & 123.5 \\
\hline C20-C9-C11 & $109.8(3)$ & 109.1 \\
\hline C11-C12-C13 & $112.5(3)$ & 112.8 \\
\hline C4-C5-C18 & $107.1(3)$ & 106.3 \\
\hline $\mathrm{O} 1-\mathrm{C} 12-\mathrm{C} 13$ & $106.6(3)$ & 107.3 \\
\hline \multicolumn{3}{|l|}{ Dihedral angles $\left(^{\circ}\right)$} \\
\hline C5-C4-C19-O4 & 75.1 & 74.7 \\
\hline C5-C4-C19-O5 & -105.4 & -106.2 \\
\hline C4-C19-O4-C21 & 178.8 & 179.5 \\
\hline C6-C7-C8-C17 & 171.0 & 168.5 \\
\hline O5-C19-O4-C21 & -0.7 & 0.4 \\
\hline C20-C9-C8-C17 & 56.0 & 60.5 \\
\hline C20-C9-C11-C12 & -60.5 & -58.7 \\
\hline C9-C11-C12-C13 & -154.9 & -165.9 \\
\hline C11-C12-C13-C16 & -88.2 & -111.1 \\
\hline C11-C12-C13-C14 & 86.8 & 67.1 \\
\hline $\mathrm{O} 1-\mathrm{C} 12-\mathrm{C} 13-\mathrm{C} 14$ & -40.1 & -58.9 \\
\hline $\mathrm{O} 1-\mathrm{C} 12-\mathrm{C} 13-\mathrm{C} 16$ & 144.9 & 122.9 \\
\hline
\end{tabular}

${ }^{\mathrm{a} E s t i m a t e d ~ s t a n d a r d ~ d e v i a t i o n ~ i n ~ p a r e n t h e s e s . ~}$ 
The ${ }^{1} \mathrm{H}$ and ${ }^{13} \mathrm{C}$ NMR spectra were calculated for $\mathbf{2}$ and TMS (internal standard) (shielding constants of 32.1843 to ${ }^{1} \mathrm{H}$ and 186.3296 to $\left.{ }^{13} \mathrm{C}\right)$. Calculated and experimental ${ }^{1} \mathrm{H}$ and ${ }^{13} \mathrm{C}$ NMR chemical shifts, as well as theoretical, predicted and experimental results for the coupling constants $\left[{ }^{\mathrm{n}} \mathrm{J}(\mathrm{H}-\mathrm{H})\right]$ of $\mathbf{2}$ are presented in the supplementary material. The most relevant statistical parameters are presented in Table 4. Figure 4 shows the correlation between calculated and experimental ${ }^{1} \mathrm{H}$ chemical shifts (A), ${ }^{13} \mathrm{C}$ chemical shifts (B) and coupling constants (C). Statistical analysis revealed good correlation for the model of ${ }^{1} \mathrm{H}$ and ${ }^{13} \mathrm{C}$ chemical shifts $\left(\mathrm{R}^{2}=99.41 \%, \mathrm{~F}=2703.85, \mathrm{~s}=0.19, \mathrm{Q}^{2}=99.26 \%\right.$ for ${ }^{1} \mathrm{H}$ and $\mathrm{R}^{2}=99.89 \%, \mathrm{~F}=18054.82, \mathrm{~s}=1.84, \mathrm{Q}^{2}=99.86 \%$ for ${ }^{13} \mathrm{C}$ ) (Figure $4 \mathrm{~A}$ and $\mathrm{B}$ ). Calculations for the coupling constant yielded slightly worse results compared to those for the chemical shifts (Figure 4 C) $\left(\mathrm{R}^{2}=94.68 \%\right.$, $\left.\mathrm{F}=289.42, \mathrm{~s}=1.22, \mathrm{Q}^{2}=92.80 \%\right)$, but they are considered satisfactory. These results confirm the relevance of the theoretical data used to confirm chemical shifts for the hydrogens $\mathrm{H}-7 \alpha$ (1.60 experimental and 1.55 predicted) and $\mathrm{H}-7 \beta$ (2.10 experimental and 2.32 predicted) because the NMR experiments performed did not allow this definition.

In Figure 4B, we can see that the general correlation to statistical analysis of ${ }^{13} \mathrm{C}$ NMR parameters is satisfactory, because all signals originating from different functional groups fall into their own distinctive regions. Thus, the overall reliability of this calculation is borne out. However some signals appear in reverse order than they would in the experimental spectrum. We note that these inversions do occur, nevertheless, only for closely spaced points, hence presumably originating from nuclei in the same functional group. The order is correct for 17 (out of 21 ) ${ }^{13} \mathrm{C}$ NMR signals, but two pairs are interchanged with respect to the experimental ordering: $\mathrm{C}-2, \mathrm{C}-3$ (theoretical $=137.6$ and $139.5 \mathrm{ppm}$; experimental $=130.0$ and $128.7 \mathrm{ppm}$, respectively) and $\mathrm{C}-10, \mathrm{C}-11$ (theoretical $=50.1$ and $51.3 \mathrm{ppm}$; experimental $=44.7$ and $44.4 \mathrm{ppm}$, respectively).

Despite the significant results in the statistical analysis, the individual differences between experimental and theoretical ${ }^{13} \mathrm{C}$ NMR data are considerably high. For example, there are chemical shifts of some $\mathrm{sp}^{2}$ carbons

Table 4. Correlation and fitting parameters for calculated NMR properties of $2^{\mathrm{a}}$

\begin{tabular}{lcccccc}
\hline & $\mathrm{A}$ & $\mathrm{b}$ & $\mathrm{R}^{2}$ & $\mathrm{~F}$ & $\mathrm{~s}$ & $\mathrm{Q}^{2}$ \\
\hline$\delta\left({ }^{1} \mathrm{H}\right)$ & -0.17 & 1.03 & $99.41 \%$ & 2703.85 & 0.19 & $99.26 \%$ \\
$\delta\left({ }^{13} \mathrm{C}\right)$ & 3.91 & 1.03 & $99.89 \%$ & 18054.82 & 1.84 & $99.86 \%$ \\
${ }^{\mathrm{n}} J(\mathrm{H}-\mathrm{H})$ & 0.05 & 1.08 & $94.68 \%$ & 289.42 & 1.22 & $92.80 \%$ \\
\hline
\end{tabular}

${ }^{a}$ Linear fitting parameters refer to $\delta_{\text {calcd }}=a+b \delta_{\text {explt }}$. For coupling constants replace $\delta$ with $J$. in which the theoretical and experimental chemical shifts differ by more than $8 \mathrm{ppm}$ (for $\mathrm{C}-3$ the residue is $10.8 \mathrm{ppm}$, for $\mathrm{C}-19$ the residue is $12.2 \mathrm{ppm})$.
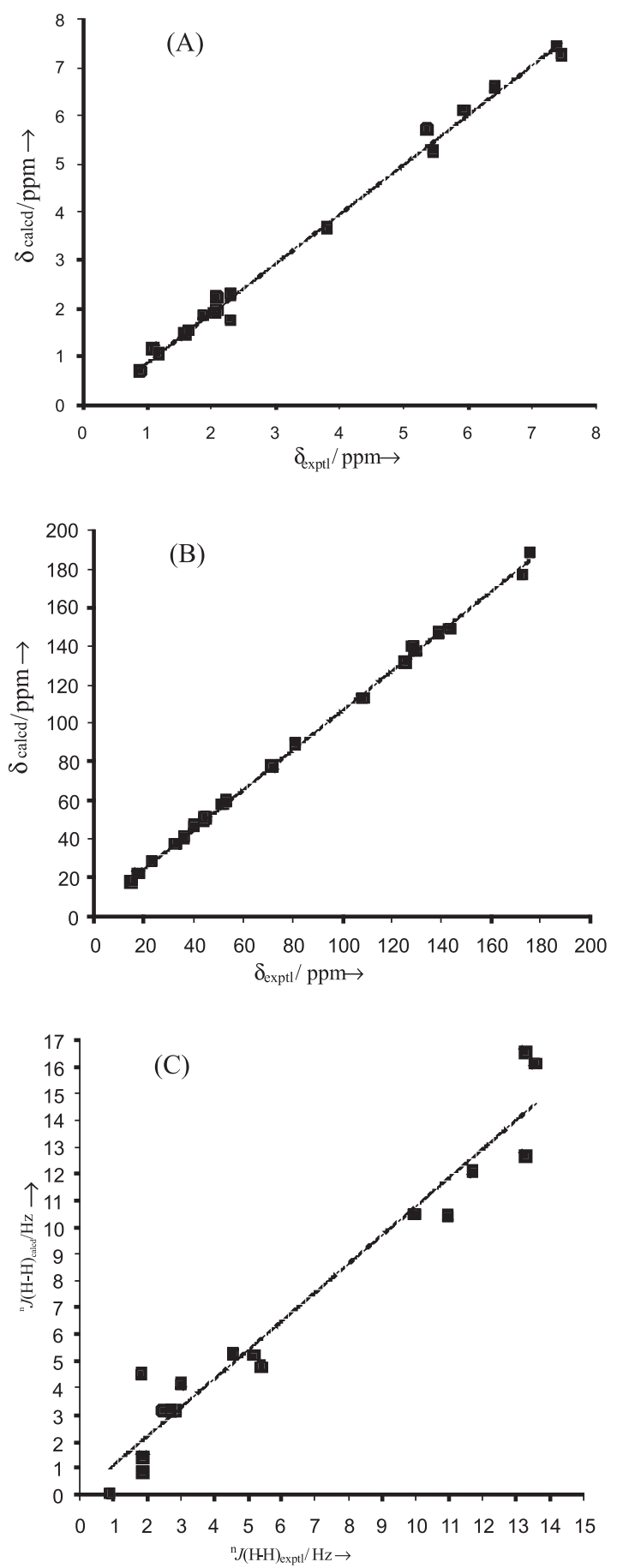

Figure 4. Correlation between calculated (B3PW91/DGDZVP) and experimental ${ }^{1} \mathrm{H}(\mathrm{A}){ }^{13} \mathrm{C}$ (B) NMR chemical shifts and coupling constant $\left[{ }^{\mathrm{J}} \mathrm{J}(\mathrm{H}-\mathrm{H})\right](\mathrm{C})$ of $\mathbf{2}$.

Recently, we successfully used three-dimensional MEP surfaces to define the most probable sites of protonation of dipyridamole and on the study of the molecular mechanisms 
the Diels-Alder reaction. ${ }^{20}$ The MEP surfaces of $\mathbf{1}$ and $\mathbf{2}$ (Figure 5) in terms of total electron density show that the lowest electronic potential is in the proximity of oxygen atoms of the lactone $(\mathrm{O} 1, \mathrm{O} 2)$, the hydroxyl group (O6) and the carbonyl group of ester (O5). The large negative potential of oxygen atoms may be regarded as a nucleophilic suction pump, ${ }^{21}$ acting as a possible magnet for electrophilic attack of $\mathrm{H}^{+}$or part of a biological receptor. The surfaces of $\mathbf{1}$ and $\mathbf{2}$ are visually similar, suggesting that $\mathbf{2}$ may have anti-ulcer activity similar to that of $\mathbf{1}$. Experimental studies are being conducted to prove this hypothesis for 2 .

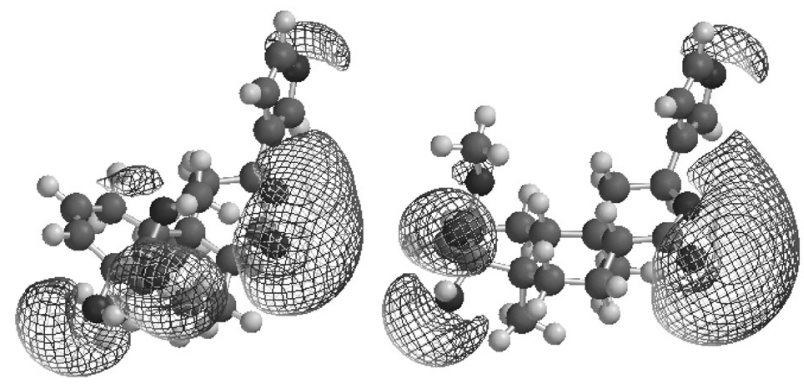

Figure 5. Three-dimensional MEP surfaces for $\mathbf{1}$ (A) and 2 (B).

\section{Experimental}

\section{General Experimental Procedures}

IR spectra were recorded on $\mathrm{NaCl}$ for compound $\mathbf{3}$ and using the pure substance for compound $2 .{ }^{1} \mathrm{H}$ and ${ }^{13} \mathrm{C} \mathrm{NMR}$ data were obtained at 300 and $75.4 \mathrm{MHz}$, respectively, in $\mathrm{CDCl}_{3}$ using the solvent peak as the internal standard. EIMS spectra were obtained at $70 \mathrm{eV}$ (probe) for compound 3 and HREI-MS data were obtained for compound 2. TLC was on silica gel $60 \mathrm{H}$ (Merck 7736) and CC on silica gel (Merck 7734).

\section{Plant Material}

Croton palanostigma Klotzsch (Euphorbiaceae) was collected in March 2007 in Terra Alta, Pará, Brazil. A voucher specimen was identified by Dr. Ricardo Secco and is deposited in the herbarium of Museu Paraense Emílio Goeldi, Belém, Pará, Brazil (MG 182.822).

\section{Extraction and isolation}

Dried and powdered bark (740 g) and leaves (590 g) of C. palanostigma were successively extracted in a Soxhlet apparatus using hexane, $\mathrm{CH}_{2} \mathrm{Cl}_{2}$ and $\mathrm{MeOH}$. During concentration of the hexane bark extract, a white solid $(1.5 \mathrm{~g})$ composed mainly of aparisthman and cordatin
(1) (1:1) precipitated. The remaining hexane bark extract was concentrated under vacuum to yield a gum (20.5 g). The gum was subjected to CC and TLC on silica gel and eluted with mixtures of hexane, EtOAc and $\mathrm{MeOH}$ in increasing order of polarity, yielding aparisthman ${ }^{2}$ (800 mg), $\mathbf{1}^{3}$ (60 mg), $\mathbf{3}^{14}$ (7 mg), ent-trachyloban18-oic $\operatorname{acid}^{22}(217 \mathrm{mg})$, ent-13-epimanoyl oxide ${ }^{19}$ (40 mg), ent-3-oxo-13-epimanoyl oxide ${ }^{19}$ (18 mg) ent$3 \beta$-hydroxy-13-epimanoyl oxide ${ }^{19}+3$ - $O$-acetylaleuritolic $\operatorname{acid}^{23}(6 \mathrm{mg})$, sitosterol ${ }^{24,25}+\operatorname{stigmasterol}^{25}(13 \mathrm{mg})$, stigmastan-3-one ${ }^{26}(5 \mathrm{mg}), 6 \beta$-hydroxystigmast-4-en-3one $^{27}+6 \beta$-hydroxystigmasta-4,22-dien-3-one ${ }^{28}$ (41 mg), stigmast-4-en-3-one ${ }^{27}+$ stigmasta-4,22-dien-3-one ${ }^{29}$ $(13 \mathrm{mg})$ and $3-O$-acetylaleuritolic $\operatorname{acid}^{23}(127 \mathrm{mg})$. The dichloromethane bark extract was concentrated under vacuum to yield a gum $(5.1 \mathrm{~g})$. The gum was subjected to CC and TLC and eluted with mixtures of hexane, EtOAc and $\mathrm{MeOH}$ in increasing order of polarity, yielding $\mathbf{1}^{3}$ (270 $\mathrm{mg}$ ) and the new compound 8-epicordatin (2) $(20 \mathrm{mg})$. The hexane leaf extract was concentrated under vacuum to yield a gum (2.6 g). The gum was subjected to $\mathrm{CC}$ and TLC and eluted with hexane, EtOAc and $\mathrm{MeOH}$ in increasing order of polarity, yielding $\alpha$-amyrenone ${ }^{30}+$ 24-methylenecycloartenone ${ }^{31}+$ lupenone $^{30,32}$ (31 mg) and $11 \alpha$-hydroxyurs-12-en-3-one ${ }^{33}$ (10 mg).

\section{Crystallography}

A single crystal of $\mathbf{2}$ was mounted on glass fiber in random orientation. Data collection was performed at room temperature using a Siemens Smart CCD diffractometer with graphite-monochromated Mo-K $\mathrm{K}_{\alpha}$ radiation $(\lambda=0.71073 \mathrm{~A})$ with a nominal crystal detection distance of $4.0 \mathrm{~cm}$. A hemisphere of data was collected based on three $\omega$-scans (starting $\omega=-28^{\circ}$ ) at values of $\phi=0^{\circ}, 90^{\circ}$ and $180^{\circ}$ with the detector at $2 \theta=28^{\circ}$. For each of these runs, frames $(606,435$ and 230 , respectively) were collected at $0.3^{\circ}$ intervals using $30 \mathrm{~s}$ per frame.

The diffraction frames were integrated using the SAINT package $^{34}$ and corrected for absorption using SADABS. ${ }^{35}$

Table 2 shows a summary of data collection and refinement conditions for the crystal structure.

\section{Computational Methods}

Since it was difficult to define chemical shifts for hydrogens $\mathrm{H}-7 \alpha$ and $\mathrm{H}-7 \beta$, theoretical NMR calculations at the B3PW91/DGDZVP level were used to confirm the assignments. Similar methods involving comparison of experimental and theoretical NMR data have been reported for aparisthman, ${ }^{36}$ strychnine, ${ }^{37}$ corianlactone, ${ }^{37}$ 
daphnipaxinin,,${ }^{37}$ boletunone $\mathrm{B},{ }^{37}$ julocrotine, ${ }^{38}$ cordatin $^{1}$ and others.

The geometry obtained from X-ray diffraction data of 2 was used as input for the full geometry optimization. This molecular conformation was optimized using the B3LYP hybrid functional, ${ }^{39}$ together with the $6-31 \mathrm{G}(d, p)$ basis in the Gaussian 03 molecular package. ${ }^{40}$ Vibrational analysis was carried out for the complete equilibrium geometry obtained by the procedure in the Gaussian 03 package at the DFT level with the B3LYP/6-31G $(d, p)$ level in the gas phase, ensuring that each gradient optimization located was indeed a true minimum energy structure (no imaginary frequencies). Normal modes were analyzed visually using Hyperchem 7.5. ${ }^{41} \mathrm{NMR}\left({ }^{1} \mathrm{H}\right.$ and ${ }^{13} \mathrm{C}$ chemical shifts and coupling constants) spectra were calculated by the B3PW91/DGDZVP method in the gas phase for the geometry optimized using the B3LYP/6-31G $(d, p)$ method. The use of a method for geometry optimization (B3LYP/6-31G $(d, p)$ ) and another one for NMR calculation has been successfully used by Bagno et al. (2006) ${ }^{37}$ to predict NMR data of several natural products. Recently, we have successfully used this methodology to study ${ }^{1} \mathrm{H}$ and ${ }^{13} \mathrm{C}$ NMR spectra of cordatin. ${ }^{1}$ In this case the geometry obtained was similar to that observed by X-Ray diffraction and could be used in calculations of NMR proprieties. All calculations were performed using Gaussian $03 .{ }^{40}$ Linear regression analysis of NMR data was performed and relevant parameters were selected: correlation coefficients $\left(R^{2}\right)$, Fisher ratio values $(F)$, the standard deviation $(s)$ and the predictive ability of the model $\left(Q^{2}\right)$. MINITAB ${ }^{\circledR}$ release 14 was used for statistical analysis. ${ }^{42}$

The MEP surface was generated using $\mathrm{HF} / 6-31 \mathrm{G}(d, p)$ with the geometry optimized in B3LYP/6-31G $(d, p)$ and an isopotential of -20.0 a.u. On the MEP surface, regions indicating excess negative potential correspond to excess negative charges, i.e., attraction of the positively charged probe. The MEP surface was calculated and analyzed visually using the PC Spartan PRO molecular package. ${ }^{43}$

\section{8-Epicordatin (2)}

Crystals; Dec. $174-176{ }^{\circ} \mathrm{C} ;[\alpha]_{\mathrm{D}}^{25}+107.35^{\circ}(c$ 0.19, $\left.\mathrm{CHCl}_{3}\right) ; \mathrm{IR} v_{\text {max }} / \mathrm{cm}^{-1}: 3540,3100,2947,1733,1704,1503$, 1429, 1367, 1246, 1132, 1089, 873; ${ }^{1} \mathrm{H}$ NMR: see Table 1 and ${ }^{13} \mathrm{C}$ NMR: see Table 1 ; HRMS $m / z$ [M+Na ${ }^{+} 397.1635$ (calc. for $\mathrm{C}_{21} \mathrm{H}_{26} \mathrm{O}_{6}+\mathrm{Na}$, 397.1627); X-ray crystallography data: see Table 3 and Figure 3.

\section{2-Oxohardwickiic acid methyl ester (3)}

Oil. $[\alpha]_{\mathrm{D}}^{25}-24.07^{\circ}\left(c 0.054, \mathrm{CHCl}_{3}\right) ; \mathrm{IR} v_{\max } / \mathrm{cm}^{-1}: 3135$, 1714, 1668, 1509, 1461, 1250, 1232, 1157, 872; ' ${ }^{1} \mathrm{H}$ NMR: see Table 1 and ${ }^{13} \mathrm{C}$ NMR: see Table 1; EIMS $\mathrm{m} / 2$ (rel. int.):
$344[\mathrm{M}]^{+}(0.3), 313[\mathrm{M}-\mathrm{OMe}]^{+}(2.6), 284\left[\mathrm{M}-\mathrm{HCO}_{2} \mathrm{Me}\right]^{+}$ (0.5), 236 (10.0), 235 (57.3), 234 [M- $\mathrm{CH}_{2}=\mathrm{C}$-furyl $]^{+}$(19.8), 233 (5.3), 220 (21.2), 219 [234-Me] ${ }^{+}(100), 218$ (13.7), 217 (7.0), 187 (15.7), 175 (3.1), 105 (4.0), 95 (10.5).

\section{Conclusions}

The chemical study of the bark and leaves of Croton palanostigma Klotzsch (Euphorbiaceae) led to the isolation of a new clerodane diterpene, 8-epicordatin. X-ray diffraction, NMR experiments and theoretical calculations were used to propose the structure of this compound. The calculated geometric parameters are close to the X-ray crystal structure indicating the accuracy of theoretical method used. The NMR theoretical values show good correlation and high predictive power and could be used to confirm the chemical shifts of hydrogens $\mathrm{H}-7 \alpha$ and $\mathrm{H}-7 \beta$. Therefore, DFT calculations can attain a considerable degree of accuracy in the prediction of the ${ }^{13} \mathrm{C}$ and ${ }^{1} \mathrm{H}$ NMR spectra of complex organic molecules such as natural products. The MEP surfaces of cordatin and 8 -epicordatin shows four sites susceptible of protonation $(\mathrm{O} 1, \mathrm{O} 2, \mathrm{O} 5$ and $\mathrm{O} 6$ positions) indicating that these species might, consequently, interact with the extracellular surface of the $\mathrm{H}^{+}, \mathrm{K}^{+}$-ATPase.

\section{Supplementary Information}

Crystallographic data for the structure reported in this paper have been deposited with the Cambridge Crystallographic Data Centre, number CCDC 666036. Copies of the data can be obtained, free of charge, on application to the Director, CCDC, 12 Union Road, Cambridge CB2 1EZ, UK (fax: +44-1223-336033 or e-mail: deposit@ccdc.cam.ac.uk).

\section{Acknowledgments}

This study was supported by Fundo Estadual de Ciência e Tecnologia, Secretaria Executiva de Ciência, Tecnologia e Meio-ambiente do Estado do Pará (FUNTEC-SECTAM); Financiadora de Estudos e Projetos (FINEP); Coordenação de Aperfeiçoamento de Pessoal e Ensino Superior (CAPES) and Conselho Nacional de Desenvolvimento Científico e Tecnológico (CNPq). The plant species was identified by Dr. Ricardo Secco of the Coordenação de Botânica/ Museu Paraense Emílio Goeldi. We would like to thank the Servei Central d'Instrumentació Científica (SCIC) of the Universitat Jaume I (Castelló, Spain) for providing us with $\mathrm{X}$-ray facilities. The authors also acknowledge the Servei d'Informatica, Universitat Jaume I for generous allotment of computer time. 


\section{References}

1. Brasil, D. S. B.; Alves, C. N.; Guilhon, G. M. S. P.; Müller, A. H.; Secco, R. de S.; Peris, G.; Llusar, R.; Int. J. Quantum Chem. 2008, 108, 2564; Brasil, D. S. B.; Müller, A. H.; Guilhon, G. M. S. P.; Alves, C. N.; Andrade, E. H. A.; da Silva, J. K. R.; Maia, J. G. S.; J. Braz. Chem. Soc. 2009, 20, 1188.

2. Müller, A. H.; Oster, B.; Schukmann, W. K.; Bartl, H.; Phytochemistry 1986, 25, 1415.

3. Dadoun, H.; Müller, A. H.; Cesario, M.; Guilhem, J.; Pascard, C.; Phytochemistry 1987, 26, 2108.

4. Hiruma-Lima, C. A.; Gracioso, J. S.; Toma, W.; Almeida, A. B.; Paula, A. C. B.; Brasil, D. S. B.; Müller, A. H.; Souza Brito, A. R. M.; Phytomedicine 2001, 8, 94.

5. Hiruma-Lima, C. A.; Gracioso, J. S.; Toma, W.; Paula, A. C. B; Almeida, A. B. A.; Brasil, D. S. B.; Müller, A. H.; Souza Brito, A. R. M.; Biol. Pharm. Bull. 2000, 23, 1465.

6. Salatino, A.; Salatino, M. L. F.; Negri, G.; J. Braz. Chem. Soc. 2007, 18, 11; Sandoval, M.; Ayala, S.; Oré, M.; Valdivieso, L.; Loli, R.; Ricra, V; Huaman, O.; An. Fac. Med. Lima 2005, 66, 119; Sandoval, M.; Ayala, S.; Oré, R.; Arroyo, J.; An. Fac. Med. Lima 2002, 63, 251; Ayala, S.; Jurupe, H.; Díaz, D.; Lock, O.; Vega, M.; Luque, J.; Garnique, M.; An. Fac. Med. Lima 2001, 62, 317; Ayala, S.; Díaz, D.; Palomino, M.; Armas, S.; Paz, J.; An. Fac. Med. Lima 1999, 60, 22; Ayala, S.; Jurupe, H.; Díaz, D.; Oré, R.; Cárdenas, W.; Espejo, L.; Rev. Situa 2000, 8, 12; Sandoval, M.; Ayala, S.; Oré, R.; Loli, A.; Huaman, O.; Valdivieso, R.; Béjar, E.; An. Fac. Med. Lima 2006, 67, 199; Sandoval, M.; Okuhama, N. N.; Clark, M.; Angeles, F. M.; Lao, J.; Bustamante, S.; Miller, M. J. S.; J. Ethnopharmacol. 2002, 80, 121.

7. Perdue, G. P.; Blomster, R. N.; Blake, D. A.; Farnsworth, N. R.; J. Pharm. Sci. 1979, 68,124.

8. Pieters, L. A. C.; Vanden Berghe, D. A.; Vlietinck, A. J.; Phytochemistry 1990, 29, 348.

9. Pieters, L.; De Bruyne, T.; Claeys, M.; Vlietinck, A.; Calomme, M.; Vanden Berghe, D.; J. Nat. Prod. 1993, 56, 899.

10. Cai, Y.; Evans, F. J.; Roberts, M. F.; Phillipson, J. D.; Zenk, M. H.; Gleba, Y. Y.; Phytochemistry 1991, 30, 2033.

11. Lorentzon, P.; Bayati, A.; Lee, H.; Andersen, K.; Ann. NY Acad. Sci. 1997, 834, 592.

12. Sachs, G.; Shin, J. M.; Briving, C.; Wallmark, B.; Hersey, S.; Annu. Rev. Pharmacol. Toxicol. 1995, 35, 277.

13. Kubota, T.; Tetrahedron 1958, 4, 68.

14. McChesney, J. D.; Silveira, E. R.; Phytochemistry 1989, 28, 3411.

15. De Araujo-Junior, V. T.; Navarro, P. A.; Silva, M. S.; Da-Cunha, E. V. L.; De Fatima Agra, M.; Gray, A. I.; Barbosa-Filho, J. M.; Ciencia (Maracaibo, Venezuela) 2002, 10, 286.

16. Palmeira-Junior, S. F.; Conserva, L. M.; Silveira, E. R.; J. Braz. Chem. Soc. 2005, 16, 1420.
17. Mambu, L.; Ramanandraibe, V.; Martin, M. T.; Blond, A.; Grellier, P.; Frappier, F.; Planta Med. 2002, 68, 377.

18. Faulkner, D. F.; Lebby, V.; Waterman, P. G.; Planta Med. 1985, 51,354 .

19. Konishi, T.; Azuma, M.; Itoga, R.; Kiyosawa, S.; Fujiwara, Y.; Shimada, Y.; Chem. Pharm. Bull. 1996, 44, 229.

20. Alves, C. N.; Da Silva, A. B. F.; Castilho, M.; Mazo, L. H.; Tabak, M.; Chem. Phys. Lett. 2001, 349, 146; Domingo, L. R.; Andres, J.; Alves, C. N.; Eur. J. Org. Chem. 2002, 15, 2557.

21. Lamotte-Brasseur, J.; Dive, G.; Dehareng, D.; Ghuysen, J. M.; J. Theor. Biol. 1990, 145, 183.

22. Leong, Y.-W.; Harrison, L. J.; Phytochemistry 1997, 45, 1457.

23. Addae-Mensah, I.; Achenbach, H.; Thoithi, G. N.; Waibel, R.; Mwangi, J. W.; Phytochemistry 1992, 31, 2055.

24. Nes, W. D.; Norton, R. A.; Benson, M.; Phytochemistry 1992, 31,805 .

25. De-Eknamkul, W.; Potduang, B.; Phytochemistry 2003, 62, 389.

26. Zhao, Y-X.; Li, C-S.; Luo, X-D.; Yi, T-M.; Zhou, J.; Chin. J. Org. Chem. 2005, 25, 1100.

27. Greca, M. D.; Monaco, P.; Previtera, L.; J. Nat. Prod. 1990, 53, 1430.

28. Asha, K. N.; Chowdhury, R.; Hasan, C. M.; Rashid, M. A.; Acta Pharm. 2004, 54, 57.

29. Almeida, M. L. S.; Kocovský, P.; Bäckvall, J-E.; J. Org. Chem. 1996, 61, 6587; Shu, Y.; Jones, S. R.; Kinney, W. A.; Selinsky, B. S.; Steroids 2002, 67, 291.

30. Olea, R. S. G.; Roque, N. F.; Quim. Nova 1990, 13, 278.

31. Barla, A.; Birman, H.; Kultur, S.; Oksuz, S.; Turk. J. Chem. 2006, 30, 325; Jayasinghe, U. L. B.; Vithana, H. S. K.; Wannigama, G. P.; Fujimoto, Y.; Fitoterapia 2001, 72, 594.

32. Ahmad, V. U.; Rahman, A. U.; Pentacyclic Triterpenoids, Handbook of Natural Products Data, Elsevier: Amsterdam, vol. 2, 1994.

33. Hou, Z-F.; Xie, Z-X.; Tu, Y-Q.; Li, Y.; Indian J. Chem., Sect. B: Org. Chem. Incl. Med. Chem. 2002, 41, 234.

34. SAINT version 6.26 A. Bruker Analytical X-ray Systems: Madison, WI.

35. Sheldrick, G. M. SADABS empirical absorption program, V 2.03, University of Gottingen, 1996.

36. Brasil, D. S. B.; Moreira, R. Y. O.; Müller, A. H.; Alves, C. N.; Int. J. Quantum Chem. 2006, 106, 2706.

37. Bagno, A.; Rastrelli, F.; Saielli, G.; Chem.-A Eur. J. 2006, 12, 5514.

38. Moreira, R. Y. O.; Brasil, D. S. B.; Alves, C. N.; Guilhon, G. M. S. P.; Santos, L. S.; Arruda, M. S. P.; Müller, A. H.; Barbosa, P. S.; Abreu, A. S.; Silva, E. O.; Rumjanek, V. M.; Souza, J. Jr.; Silva, A. B. F.; Santos, R. H. A.; Int. J. Quantum Chem. 2008, 108, 513.

39. Becke, A. D.; J. Chem. Phys. 1993, 98, 5648; Lee, C.; Yang, W.; Parr, R. G.; Phys. Rev. B 1988, 37, 785.

40. Frisch, M. J.; Trucks, G. W.; Schlegel, H. B.; Scuseria, G. E.; Robb, M. A.; Cheeseman, J. R.; Montgomery, J. A., Jr.; Vreven, 
T.; Kudin, K. N.; Burant, J. C.; Millam, J. M.; Iyengar, S. S.; Tomasi, J.; Barone, V.; Mennucci, B.; Cossi, M.; Scalmani, G.; Rega, N.; Petersson, G. A.; Nakatsuji, H.; Hada, M.; Ehara, M.; Toyota, K.; Fukuda, R.; Hasegawa, J.; Ishida, M.; Nakajima, T.; Honda, Y.; Kitao, O.; Nakai, H.; Klene, M.; Li, X.; Knox, J. E.; Hratchian, H. P.; Cross, J. B.; Adamo, C.; Jaramillo, J.; Gomperts, R.; Stratmann, R. E.; Yazyev, O.; Austin, A. J.; Cammi, R.; Pomelli, C.; Ochterski, J. W.; Ayala, P. Y.; Morokuma, K.; Voth, G. A.; Salvador, P.; Dannenberg, J. J.; Zakrzewski, V. G.; Dapprich, S.; Daniels, A. D.; Strain, M. C.; Farkas, O.; Malick, D. K.; Rabuck, A. D.; Raghavachari, K.; Foresman, J. B.; Ortiz, J. V.; Cui, Q.; Baboul, A. G.; Clifford, S.;
Cioslowski, J.; Stefanov, B. B.; Liu, G.; Liashenko, A.; Piskorz, P.; Komaromi, I.; Martin, R. L.; Fox, D. J.; Keith, T.; Al-Laham, M. A.; Peng, C. Y.; Nanayakkara, A.; Challacombe, M.; Gill, P. M. W.; Johnson, B.; Chen, W.; Wong, M. W.; Gonzalez, C.; Pople, J. A.; Gaussian 03, Revision B.04. Gaussian: Pittsburgh, PA, 2003.

41. HyperChem ${ }^{\mathrm{TM}}$ Release 7.5 for Windows Molecular Modeling System. Hypercube: Gainesville, USA, 2002.

42. MINITAB Release 14 for Windows. Minitab: State College, PA, 2003.

43. PC Spartan-Pro, version 1.0; Wavefunction, Inc.: Irvine, CA, USA, 1999. 


\title{
Isolation, X-ray Crystal Structure and Theoretical Calculations of the New Compound 8-epicordatin and Identification of Others Terpenes and Steroids from the Bark and Leaves of Croton palanostigma Klotzsch
}

\author{
Davi S. B. Brasil, ${ }^{a, b}$ Adolfo H. Müller, ${ }^{*, a, c}$ Gisele M. S. P. Guilhon, ${ }^{a}$ Cláudio N. Alves, ${ }^{a}$ \\ Gabriel Peris, ${ }^{d}$ Rosa Llusar ${ }^{d}$ and Vicent Moliner ${ }^{d}$ \\ anstituto de Ciências Exatas e Naturais, Universidade Federal do Pará, Av. Augusto Corrêa, 01, \\ 66075-900 Belém-PA, Brazil \\ ${ }^{b}$ Faculdade de Engenharia Química, Instituto de Tecnologia, Universidade Federal do Pará, \\ Av. Augusto Corrêa, 01, 66075-900 Belém-PA, Brazil \\ ${ }^{c}$ Centro Universitário do Estado do Pará, Av Nazaré, 630, 66035-170 Belém-PA, Brazil \\ ${ }^{d}$ Departament de Química Física i Analítica, Universitat Jaume I, 12071, Castellón, Spain
}

Table S1. Atomic coordinates $\left(\mathrm{x} 10^{4}\right)$ and equivalent isotropic displacement parameters $\left(\AA^{2} \times 10^{3}\right)$ for $2 \mathrm{U}(\mathrm{eq})$ is defined as one third of the trace of the orthogonalized $\mathrm{U}^{\mathrm{ij}}$ tensor

\begin{tabular}{lcccc}
\hline & $\mathrm{x}$ & $\mathrm{y}$ & $\mathrm{z}$ & $\mathrm{U}(\mathrm{eq})$ \\
\hline $\mathrm{O}(4)$ & $2238(2)$ & $4025(2)$ & $774(1)$ & $57(1)$ \\
$\mathrm{O}(5)$ & $2280(2)$ & $5725(2)$ & $438(1)$ & $73(1)$ \\
$\mathrm{C}(2)$ & $2821(3)$ & $4243(3)$ & $2029(1)$ & $53(1)$ \\
$\mathrm{C}(19)$ & $2505(2)$ & $5093(2)$ & $781(1)$ & $49(1)$ \\
$\mathrm{C}(9)$ & $5490(2)$ & $3141(3)$ & $1335(1)$ & $52(1)$ \\
$\mathrm{O}(6)$ & $3060(3)$ & $6646(2)$ & $1274(1)$ & $80(1)$ \\
$\mathrm{C}(1)$ & $3861(2)$ & $3587(2)$ & $1948(1)$ & $49(1)$ \\
$\mathrm{C}(5)$ & $4368(2)$ & $5055(3)$ & $1284(1)$ & $49(1)$ \\
$\mathrm{O}(1)$ & $7063(2)$ & $1733(4)$ & $825(1)$ & $96(1)$ \\
$\mathrm{C}(10)$ & $4370(2)$ & $3781(2)$ & $1419(1)$ & $42(1)$ \\
$\mathrm{C}(8)$ & $5963(2)$ & $3455(3)$ & $806(1)$ & $63(1)$ \\
$\mathrm{C}(11)$ & $5223(2)$ & $1897(3)$ & $1284(1)$ & $60(1)$ \\
$\mathrm{C}(3)$ & $2486(3)$ & $5056(3)$ & $1727(1)$ & $56(1)$ \\
$\mathrm{C}(4)$ & $3117(3)$ & $5450(2)$ & $1269(1)$ & $51(1)$ \\
\hline
\end{tabular}

\begin{tabular}{lcccc}
\hline & $\mathrm{x}$ & $\mathrm{y}$ & $\mathrm{z}$ & $\mathrm{U}(\mathrm{eq})$ \\
\hline $\mathrm{C}(13)$ & $5926(3)$ & $123(4)$ & $880(1)$ & $73(1)$ \\
$\mathrm{C}(7)$ & $6060(3)$ & $4715(4)$ & $720(1)$ & $77(1)$ \\
$\mathrm{C}(20)$ & $6359(3)$ & $3319(4)$ & $1759(1)$ & $73(1)$ \\
$\mathrm{O}(2)$ & $7815(2)$ & $3222(4)$ & $483(1)$ & $119(1)$ \\
$\mathrm{C}(18)$ & $4970(3)$ & $5775(3)$ & $1692(1)$ & $72(1)$ \\
$\mathrm{C}(14)$ & $5757(4)$ & $-36(4)$ & $359(2)$ & $92(1)$ \\
$\mathrm{C}(17)$ & $7009(3)$ & $2817(6)$ & $695(1)$ & $90(2)$ \\
$\mathrm{O}(10)$ & $5358(4)$ & $-1610(3)$ & $747(2)$ & $130(1)$ \\
$\mathrm{C}(6)$ & $4921(3)$ & $5245(3)$ & $762(1)$ & $66(1)$ \\
$\mathrm{C}(12)$ & $6241(3)$ & $1182(4)$ & $1146(1)$ & $78(1)$ \\
$\mathrm{C}(15)$ & $5419(5)$ & $-1082(4)$ & $295(2)$ & $104(2)$ \\
$\mathrm{C}(16)$ & $5672(5)$ & $-853(6)$ & $1105(2)$ & $111(2)$ \\
$\mathrm{C}(21)$ & $1641(3)$ & $3616(3)$ & $336(1)$ & $68(1)$ \\
\hline
\end{tabular}

*e-mail: muller@ufpa.br, muller@cesupa.br 
Table S2. Bond lengths $[\AA]$ and angles $\left[{ }^{\circ}\right]$ for $\mathbf{2}$

\begin{tabular}{|c|c|c|c|}
\hline $\mathrm{O}(4)-\mathrm{C}(19)$ & $1.317(4)$ & $\mathrm{C}(20)-\mathrm{C}(9)-\mathrm{C}(10)$ & $114.2(2)$ \\
\hline $\mathrm{O}(4)-\mathrm{C}(21)$ & $1.437(3)$ & $\mathrm{C}(8)-\mathrm{C}(9)-\mathrm{C}(10)$ & $108.9(2)$ \\
\hline $\mathrm{O}(5)-\mathrm{C}(19)$ & $1.205(3)$ & $\mathrm{C}(2)-\mathrm{C}(1)-\mathrm{C}(10)$ & $112.4(2)$ \\
\hline $\mathrm{C}(2)-\mathrm{C}(3)$ & $1.315(4)$ & $C(6)-C(5)-C(18)$ & $109.3(2)$ \\
\hline $\mathrm{C}(2)-\mathrm{C}(1)$ & $1.486(4)$ & $C(6)-C(5)-C(10)$ & $110.2(3)$ \\
\hline$C(19)-C(4)$ & $1.533(4)$ & $\mathrm{C}(18)-\mathrm{C}(5)-\mathrm{C}(10)$ & $112.6(2)$ \\
\hline $\mathrm{C}(9)-\mathrm{C}(11)$ & $1.528(5)$ & $C(6)-C(5)-C(4)$ & $110.1(2)$ \\
\hline $\mathrm{C}(9)-\mathrm{C}(20)$ & $1.536(4)$ & $\mathrm{C}(18)-\mathrm{C}(5)-\mathrm{C}(4)$ & 107.1(3) \\
\hline $\mathrm{C}(9)-\mathrm{C}(8)$ & $1.541(4)$ & $C(10)-C(5)-C(4)$ & $107.5(2)$ \\
\hline $\mathrm{C}(9)-\mathrm{C}(10)$ & $1.558(4)$ & $\mathrm{C}(17)-\mathrm{O}(1)-\mathrm{C}(12)$ & $123.5(3)$ \\
\hline $\mathrm{O}(6)-\mathrm{C}(4)$ & $1.432(4)$ & $\mathrm{C}(1)-\mathrm{C}(10)-\mathrm{C}(9)$ & $113.3(2)$ \\
\hline$C(1)-C(10)$ & $1.530(3)$ & $C(1)-C(10)-C(5)$ & $110.6(2)$ \\
\hline$C(5)-C(6)$ & $1.535(4)$ & $\mathrm{C}(9)-\mathrm{C}(10)-\mathrm{C}(5)$ & $116.6(2)$ \\
\hline$C(5)-C(18)$ & $1.549(4)$ & $\mathrm{C}(17)-\mathrm{C}(8)-\mathrm{C}(7)$ & $114.3(3)$ \\
\hline$C(5)-C(10)$ & $1.565(4)$ & $\mathrm{C}(17)-\mathrm{C}(8)-\mathrm{C}(9)$ & $111.0(3)$ \\
\hline$C(5)-C(4)$ & $1.570(4)$ & $\mathrm{C}(7)-\mathrm{C}(8)-\mathrm{C}(9)$ & $113.6(3)$ \\
\hline $\mathrm{O}(1)-\mathrm{C}(17)$ & $1.344(6)$ & $\mathrm{C}(9)-\mathrm{C}(11)-\mathrm{C}(12)$ & $113.4(3)$ \\
\hline $\mathrm{O}(1)-\mathrm{C}(12)$ & $1.451(5)$ & $\mathrm{C}(2)-\mathrm{C}(3)-\mathrm{C}(4)$ & 124.1(3) \\
\hline $\mathrm{C}(8)-\mathrm{C}(17)$ & $1.493(6)$ & $\mathrm{O}(6)-\mathrm{C}(4)-\mathrm{C}(3)$ & $106.5(3)$ \\
\hline$C(8)-C(7)$ & $1.529(6)$ & $\mathrm{O}(6)-\mathrm{C}(4)-\mathrm{C}(19)$ & $105.3(2)$ \\
\hline$C(11)-C(12)$ & $1.531(5)$ & $\mathrm{C}(3)-\mathrm{C}(4)-\mathrm{C}(19)$ & $109.9(2)$ \\
\hline $\mathrm{C}(3)-\mathrm{C}(4)$ & $1.494(4)$ & $\mathrm{O}(6)-\mathrm{C}(4)-\mathrm{C}(5)$ & $110.2(2)$ \\
\hline$C(13)-C(16)$ & $1.342(7)$ & $\mathrm{C}(3)-\mathrm{C}(4)-\mathrm{C}(5)$ & $111.5(2)$ \\
\hline $\mathrm{C}(13)-\mathrm{C}(14)$ & $1.393(6)$ & $\mathrm{C}(19)-\mathrm{C}(4)-\mathrm{C}(5)$ & $113.1(2)$ \\
\hline $\mathrm{C}(13)-\mathrm{C}(12)$ & $1.494(6)$ & $\mathrm{C}(16)-\mathrm{C}(13)-\mathrm{C}(14)$ & $106.1(5)$ \\
\hline$C(7)-C(6)$ & $1.507(6)$ & $\mathrm{C}(16)-\mathrm{C}(13)-\mathrm{C}(12)$ & $126.3(4)$ \\
\hline $\mathrm{O}(2)-\mathrm{C}(17)$ & $1.214(5)$ & $\mathrm{C}(14)-\mathrm{C}(13)-\mathrm{C}(12)$ & $127.5(4)$ \\
\hline$C(14)-C(15)$ & $1.326(7)$ & $\mathrm{C}(6)-\mathrm{C}(7)-\mathrm{C}(8)$ & $109.6(3)$ \\
\hline $\mathrm{O}(10)-\mathrm{C}(15)$ & $1.342(7)$ & $\mathrm{C}(15)-\mathrm{C}(14)-\mathrm{C}(13)$ & $107.3(4)$ \\
\hline $\mathrm{O}(10)-\mathrm{C}(16)$ & $1.356(7)$ & $\mathrm{O}(2)-\mathrm{C}(17)-\mathrm{O}(1)$ & $117.6(4)$ \\
\hline $\mathrm{C}(19)-\mathrm{O}(4)-\mathrm{C}(21)$ & $117.5(2)$ & $\mathrm{O}(2)-\mathrm{C}(17)-\mathrm{C}(8)$ & $123.5(6)$ \\
\hline$C(3)-C(2)-C(1)$ & 124.1(3) & $\mathrm{O}(1)-\mathrm{C}(17)-\mathrm{C}(8)$ & $118.9(4)$ \\
\hline $\mathrm{O}(5)-\mathrm{C}(19)-\mathrm{O}(4)$ & $123.0(3)$ & $C(15)-O(10)-C(16)$ & $106.3(4)$ \\
\hline $\mathrm{O}(5)-\mathrm{C}(19)-\mathrm{C}(4)$ & $123.6(3)$ & $\mathrm{C}(7)-\mathrm{C}(6)-\mathrm{C}(5)$ & $113.1(3)$ \\
\hline $\mathrm{O}(4)-\mathrm{C}(19)-\mathrm{C}(4)$ & $113.4(2)$ & $\mathrm{O}(1)-\mathrm{C}(12)-\mathrm{C}(13)$ & $106.6(3)$ \\
\hline $\mathrm{C}(11)-\mathrm{C}(9)-\mathrm{C}(20)$ & $109.8(3)$ & $\mathrm{O}(1)-\mathrm{C}(12)-\mathrm{C}(11)$ & $115.0(4)$ \\
\hline $\mathrm{C}(11)-\mathrm{C}(9)-\mathrm{C}(8)$ & $103.6(2)$ & $\mathrm{C}(13)-\mathrm{C}(12)-\mathrm{C}(11)$ & $112.5(3)$ \\
\hline $\mathrm{C}(20)-\mathrm{C}(9)-\mathrm{C}(8)$ & $111.5(2)$ & $\mathrm{C}(14)-\mathrm{C}(15)-\mathrm{O}(10)$ & $110.4(5)$ \\
\hline $\mathrm{C}(11)-\mathrm{C}(9)-\mathrm{C}(10)$ & $108.1(2)$ & $\mathrm{C}(13)-\mathrm{C}(16)-\mathrm{O}(10)$ & $109.9(4)$ \\
\hline
\end{tabular}

Symmetry transformations used to generate equivalent atoms 
Table S3. Anisotropic displacement parameters $\left(\AA^{2} \times 10^{3}\right)$ for 2 . The anisotropic displacement factor exponent takes the form: $-2 \pi^{2}\left[h^{2} a^{* 2} U^{11}\right.$ $\left.+\ldots+2 \mathrm{~h} \mathrm{k} \mathrm{a}^{*} \mathrm{~b}^{*} \mathrm{U}^{12}\right]$

\begin{tabular}{|c|c|c|c|c|c|c|}
\hline & $\mathrm{U}^{11}$ & $\mathrm{U}^{22}$ & $\mathrm{U}^{33}$ & $\mathrm{U}^{23}$ & $\mathrm{U}^{13}$ & $\mathrm{U}^{12}$ \\
\hline $\mathrm{O}(4)$ & 69(1) & $50(1)$ & $53(1)$ & $3(1)$ & $-18(1)$ & $-9(1)$ \\
\hline $\mathrm{O}(5)$ & $95(2)$ & $63(1)$ & 61(1) & $13(1)$ & $-22(1)$ & $-3(1)$ \\
\hline$C(2)$ & $60(2)$ & $60(2)$ & $37(1)$ & $-7(1)$ & 13(1) & $3(1)$ \\
\hline$C(19)$ & $54(2)$ & $51(2)$ & $43(1)$ & $3(1)$ & 1(1) & $-1(1)$ \\
\hline C(9) & $33(1)$ & $88(2)$ & $35(1)$ & $-9(1)$ & $-1(1)$ & $-5(1)$ \\
\hline $\mathrm{O}(6)$ & $123(2)$ & $44(1)$ & $73(1)$ & $-6(1)$ & $-14(2)$ & $-7(1)$ \\
\hline $\mathrm{C}(1)$ & $49(2)$ & $57(2)$ & $40(1)$ & $3(1)$ & $8(1)$ & $0(1)$ \\
\hline$C(5)$ & $53(2)$ & $59(2)$ & $35(1)$ & $-1(1)$ & $-1(1)$ & $-20(1)$ \\
\hline $\mathrm{O}(1)$ & $41(1)$ & $150(3)$ & $96(2)$ & $-35(2)$ & 12(1) & $15(2)$ \\
\hline $\mathrm{C}(10)$ & $35(1)$ & $59(2)$ & $32(1)$ & $-3(1)$ & $1(1)$ & $-6(1)$ \\
\hline$C(8)$ & 39(2) & $114(3)$ & $36(1)$ & $-12(2)$ & $3(1)$ & $-19(2)$ \\
\hline $\mathrm{C}(11)$ & $39(2)$ & $87(2)$ & $53(2)$ & $-9(2)$ & $0(1)$ & $13(2)$ \\
\hline$C(3)$ & $62(2)$ & $64(2)$ & 41(1) & $-8(1)$ & $5(1)$ & $10(2)$ \\
\hline $\mathrm{C}(4)$ & $67(2)$ & $42(2)$ & $45(1)$ & $-3(1)$ & $-4(1)$ & $-6(1)$ \\
\hline$C(13)$ & $62(2)$ & $97(3)$ & $58(2)$ & 11(2) & $5(2)$ & $47(2)$ \\
\hline$C(7)$ & $59(2)$ & $128(3)$ & $44(2)$ & $3(2)$ & $8(2)$ & $-39(2)$ \\
\hline $\mathrm{C}(20)$ & $42(2)$ & $134(3)$ & $44(2)$ & $-10(2)$ & $-7(1)$ & $-7(2)$ \\
\hline $\mathrm{O}(2)$ & $55(2)$ & 211(4) & $92(2)$ & $-36(2)$ & $37(2)$ & $-28(2)$ \\
\hline$C(18)$ & $89(3)$ & $78(2)$ & $48(2)$ & $-8(2)$ & $-5(2)$ & $-39(2)$ \\
\hline$C(14)$ & $118(4)$ & $82(3)$ & $77(3)$ & $8(2)$ & $0(2)$ & $32(3)$ \\
\hline $\mathrm{C}(17)$ & $47(2)$ & $173(5)$ & $52(2)$ & $-38(3)$ & 11(2) & $-4(3)$ \\
\hline $\mathrm{O}(10)$ & $149(3)$ & $99(3)$ & $142(3)$ & $26(3)$ & $40(3)$ & $40(2)$ \\
\hline$C(6)$ & $69(2)$ & $82(2)$ & $46(2)$ & $7(2)$ & $4(2)$ & $-33(2)$ \\
\hline$C(12)$ & $49(2)$ & $129(4)$ & $57(2)$ & $-8(2)$ & $-4(2)$ & $34(2)$ \\
\hline$C(15)$ & $133(4)$ & $69(3)$ & $111(4)$ & $-17(3)$ & $-10(3)$ & $28(3)$ \\
\hline$C(16)$ & $118(4)$ & $125(4)$ & $89(3)$ & $27(3)$ & $33(3)$ & $52(3)$ \\
\hline$C(21)$ & $73(2)$ & $68(2)$ & $62(2)$ & $-4(2)$ & $-24(2)$ & $-11(2)$ \\
\hline
\end{tabular}

Table S4. Hydrogen coordinates (x 104) and isotropic displacement parameters $\left(\AA^{2} \times 10^{3}\right)$ for 2

\begin{tabular}{|c|c|c|c|c|}
\hline & $\mathrm{x}$ & $\mathrm{y}$ & $\mathrm{z}$ & $\mathrm{U}(\mathrm{eq})$ \\
\hline $\mathrm{H}(2)$ & 2379 & 4068 & 2310 & 63 \\
\hline $\mathrm{H}(6)$ & 2917 & 6874 & 986 & 120 \\
\hline $\mathrm{H}(1 \mathrm{~A})$ & 3696 & 2798 & 1989 & 59 \\
\hline $\mathrm{H}(1 \mathrm{~B})$ & 4404 & 3792 & 2207 & 59 \\
\hline $\mathrm{H}(10)$ & 3841 & 3439 & 1180 & 50 \\
\hline $\mathrm{H}(8)$ & 5411 & 3191 & 557 & 75 \\
\hline $\mathrm{H}(11 \mathrm{~A})$ & 4656 & 1800 & 1023 & 72 \\
\hline $\mathrm{H}(11 \mathrm{~B})$ & 4914 & 1631 & 1604 & 72 \\
\hline $\mathrm{H}(3)$ & 1813 & 5408 & 1804 & 67 \\
\hline $\mathrm{H}(7 \mathrm{~A})$ & 6558 & 5037 & 973 & 92 \\
\hline $\mathrm{H}(7 \mathrm{~B})$ & 6371 & 4859 & 384 & 92 \\
\hline $\mathrm{H}(20 \mathrm{~A})$ & 6035 & 3130 & 2083 & 110 \\
\hline $\mathrm{H}(20 \mathrm{~B})$ & 6590 & 4087 & 1762 & 110 \\
\hline $\mathrm{H}(20 \mathrm{C})$ & 6996 & 2850 & 1697 & 110 \\
\hline $\mathrm{H}(18 \mathrm{~A})$ & 5725 & 5516 & 1732 & 108 \\
\hline $\mathrm{H}(18 \mathrm{~B})$ & 4583 & 5712 & 2012 & 108 \\
\hline $\mathrm{H}(18 \mathrm{C})$ & 4976 & 6542 & 1584 & 108 \\
\hline $\mathrm{H}(14)$ & 5861 & 494 & 103 & 111 \\
\hline $\mathrm{H}(6 \mathrm{~A})$ & 4441 & 4940 & 497 & 79 \\
\hline $\mathrm{H}(6 \mathrm{~B})$ & 4990 & 6042 & 702 & 79 \\
\hline $\mathrm{H}(12)$ & 6613 & 977 & 1466 & 94 \\
\hline $\mathrm{H}(15)$ & 5248 & -1405 & -19 & 125 \\
\hline $\mathrm{H}(16)$ & 5705 & -991 & 1454 & 133 \\
\hline $\mathrm{H}(21 \mathrm{~A})$ & 941 & 4001 & 306 & 102 \\
\hline $\mathrm{H}(21 \mathrm{~B})$ & 1507 & 2829 & 374 & 102 \\
\hline $\mathrm{H}(21 \mathrm{C})$ & 2078 & 3743 & 33 & 102 \\
\hline
\end{tabular}


Table S5. Theoretical and Experimental NMR Chemical Shifts for 2

\begin{tabular}{|c|c|c|c|c|}
\hline \multirow[t]{2}{*}{ Position } & \multicolumn{2}{|c|}{$\begin{array}{l}\text { 8-epi-cordatin }(2) \\
\text { calculated }^{\mathrm{a}}\end{array}$} & \multicolumn{2}{|c|}{$\begin{array}{l}\text { 8-epi-cordatin }(\mathbf{2}) \\
\text { experimental }\end{array}$} \\
\hline & $\delta_{\mathrm{C}}$ & $\delta_{\mathrm{H}}$ & $\delta_{\mathrm{C}}$ & $\delta_{\mathrm{H}}$ \\
\hline 1 & 28.0 & 1.95 & 22.9 & 2.1 \\
\hline 2 & 137.6 & 6.14 & 130.0 & 5.95 \\
\hline 3 & 139.5 & 5.71 & 128.7 & 5.36 \\
\hline 4 & 88.8 & & 81.2 & \\
\hline 5 & 46.7 & & 40.5 & \\
\hline 6 & 37.0 & $\begin{array}{l}\alpha-1.87 \\
\beta-0.71\end{array}$ & 33.2 & $\begin{array}{l}\alpha-1.86 \\
\beta-0.91\end{array}$ \\
\hline 7 & 22.5 & $\begin{array}{l}\alpha-1.43 \\
\beta-2.22\end{array}$ & 18.1 & $\begin{array}{l}\alpha-1.60 \\
\beta-2.10\end{array}$ \\
\hline 8 & 57.7 & 1.90 & 51.4 & 2.07 \\
\hline 9 & 40.7 & & 36.4 & \\
\hline 10 & 50.1 & 2.28 & 44.7 & 2.33 \\
\hline 11 & 51.3 & $\begin{array}{l}\alpha-1.79 \\
\beta-1.54\end{array}$ & 44.4 & $\begin{array}{l}\alpha-2.29 \\
\beta-1.67\end{array}$ \\
\hline 12 & 77.0 & 5.26 & 71.9 & 5.48 \\
\hline 13 & 131.5 & & 125.8 & \\
\hline 14 & 113.2 & 6.57 & 108.5 & 6.41 \\
\hline 15 & 149.5 & 7.45 & 143.7 & 7.41 \\
\hline 16 & 146.4 & 7.26 & 139.3 & 7.44 \\
\hline 17 & 177.1 & & 171.9 & \\
\hline 18 & 17.5 & 1.15 & 15.2 & 1.12 \\
\hline 19 & 187.7 & & 175.5 & \\
\hline 20 & 18.7 & 1.04 & 15.4 & 1.17 \\
\hline 21 & 59.4 & 3.66 & 53.2 & 3.81 \\
\hline
\end{tabular}

${ }^{a}$ NMR chemical shifts calculated at B3PW91/DGDZVP.
Table S6. Predicted, calculated and Experimental ${ }^{1} \mathrm{H}$ NMR coupling constant $\left[{ }^{\mathrm{n}} J(\mathrm{H}-\mathrm{H})\right](\mathrm{Hz})$ for 2

\begin{tabular}{lccc}
\hline Coupling & experimental & $\begin{array}{c}\text { B3PW91/ } \\
\text { DGDZVP }\end{array}$ & Predicted $^{\text {a }}$ \\
\hline $2-1 \alpha$ & 2.9 & 3.2 & 2.9 \\
$2-1 \beta$ & 4.6 & 5.3 & 4.8 \\
$2-3$ & 10 & 10.5 & 9.7 \\
$3-1 \alpha$ & 1.8 & 4.5 & 4.2 \\
$3-1 \beta$ & 2.5 & 3.2 & 2.9 \\
$6 \alpha-6 \beta$ & 13.3 & 16.5 & 15.3 \\
$6 \alpha-7 \alpha$ & 2.7 & 3.2 & 2.9 \\
$6 \alpha-7 \beta$ & 2.7 & 3.2 & 2.9 \\
$6 \beta-7 \alpha$ & 13.3 & 12.7 & 11.7 \\
$6 \beta-7 \alpha$ & 3.0 & 4.1 & 3.8 \\
$10-1 \alpha$ & 11.0 & 10.4 & 9.6 \\
$10-1 \beta$ & 5.2 & 5.2 & 4.8 \\
$11 \alpha-11 \beta$ & 13.6 & 16.2 & 15.0 \\
$11 \alpha-12$ & 5.4 & 4.8 & 4.4 \\
$12-11 \beta$ & 11.7 & 12.1 & 11.2 \\
$14-15$ & 1.9 & 1.4 & 1.3 \\
$14-16$ & 0.9 & 0.1 & 0.0 \\
$15-16$ & 1.9 & 0.9 & 0.8 \\
\hline${ }^{2}$ Predicted after linear regression using the equation: $J_{\text {calcd }}=a+b J_{\text {explt }}$ \\
6
\end{tabular}




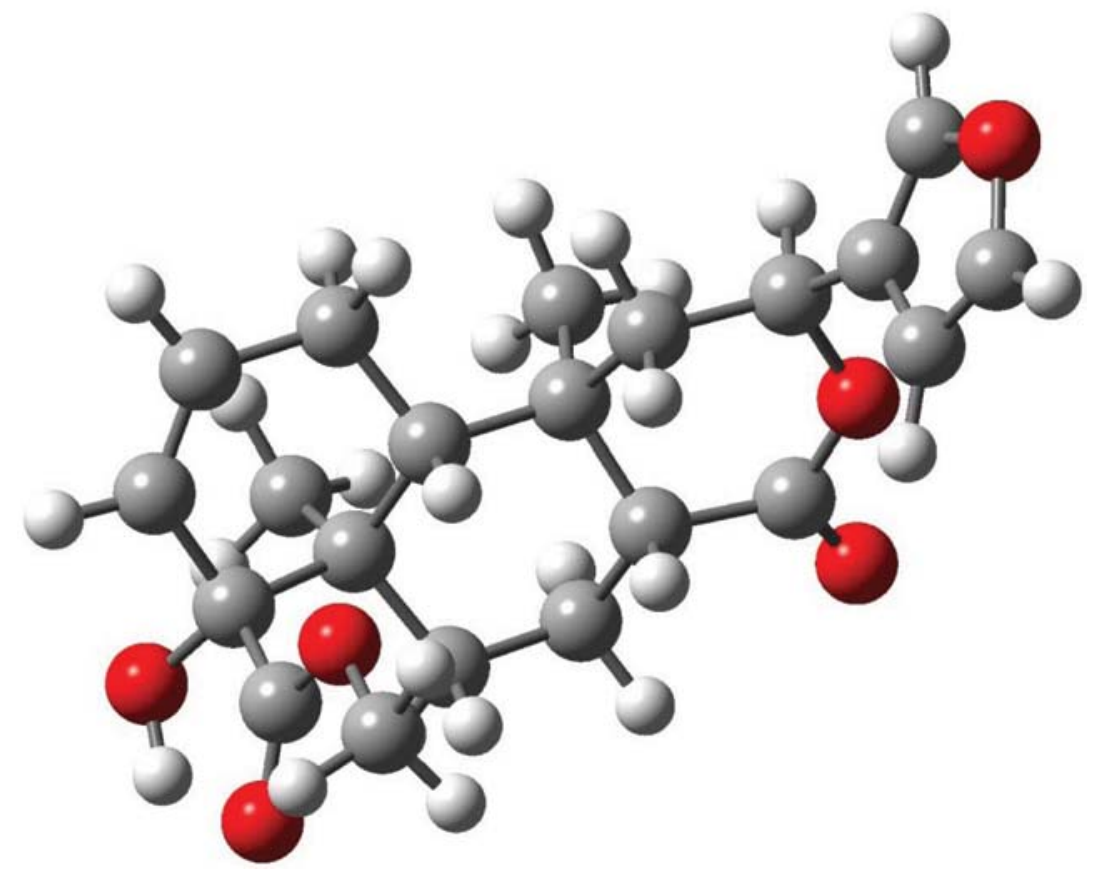

Figure S1. B3LYP/6-31G $(d, p)$ optimized structure of 2.

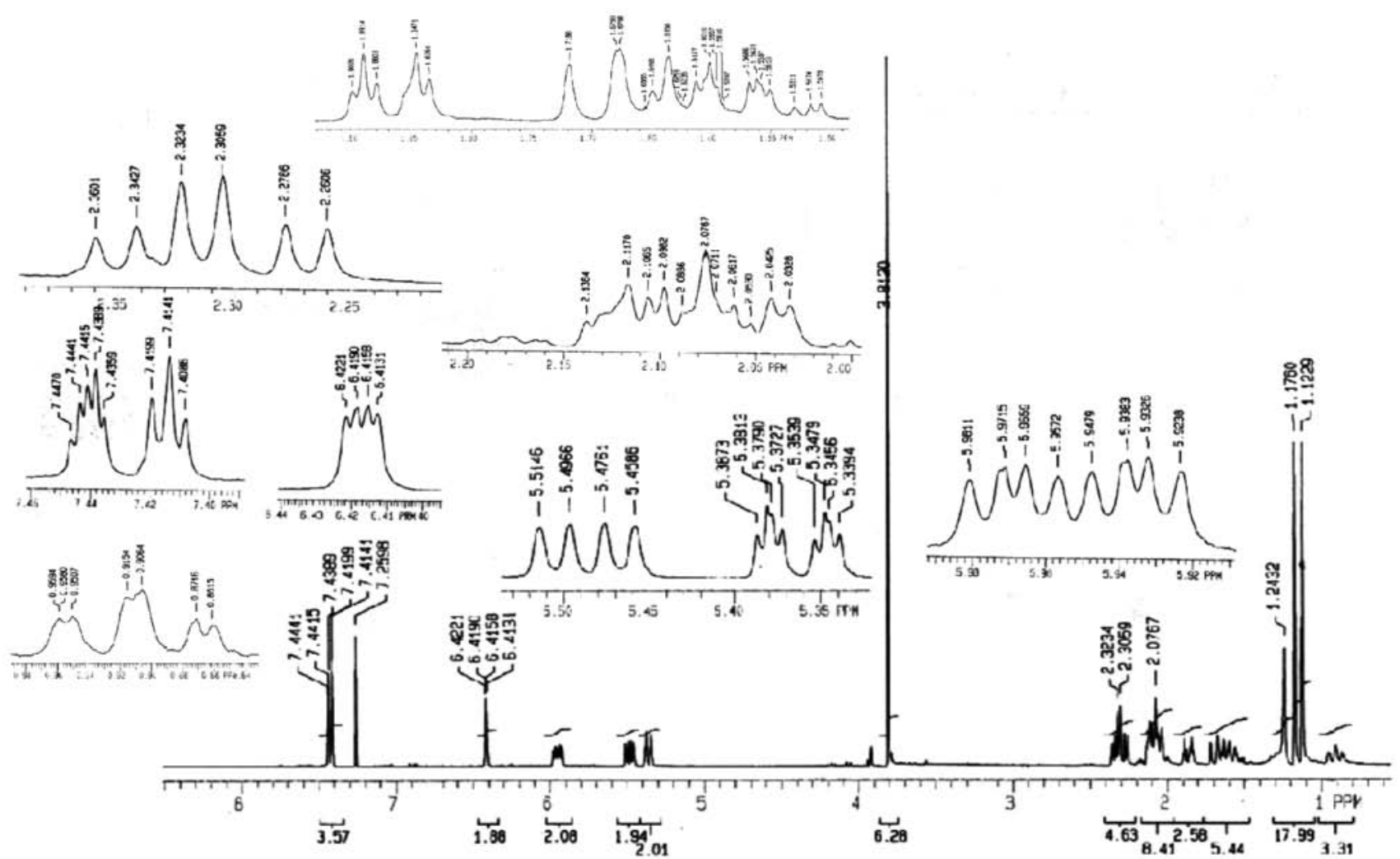

Figure S2. ${ }^{1} \mathrm{H}$ NMR $\left(300 \mathrm{MHz}, \mathrm{CDCl}_{3}\right)$ of the new compound 2. 


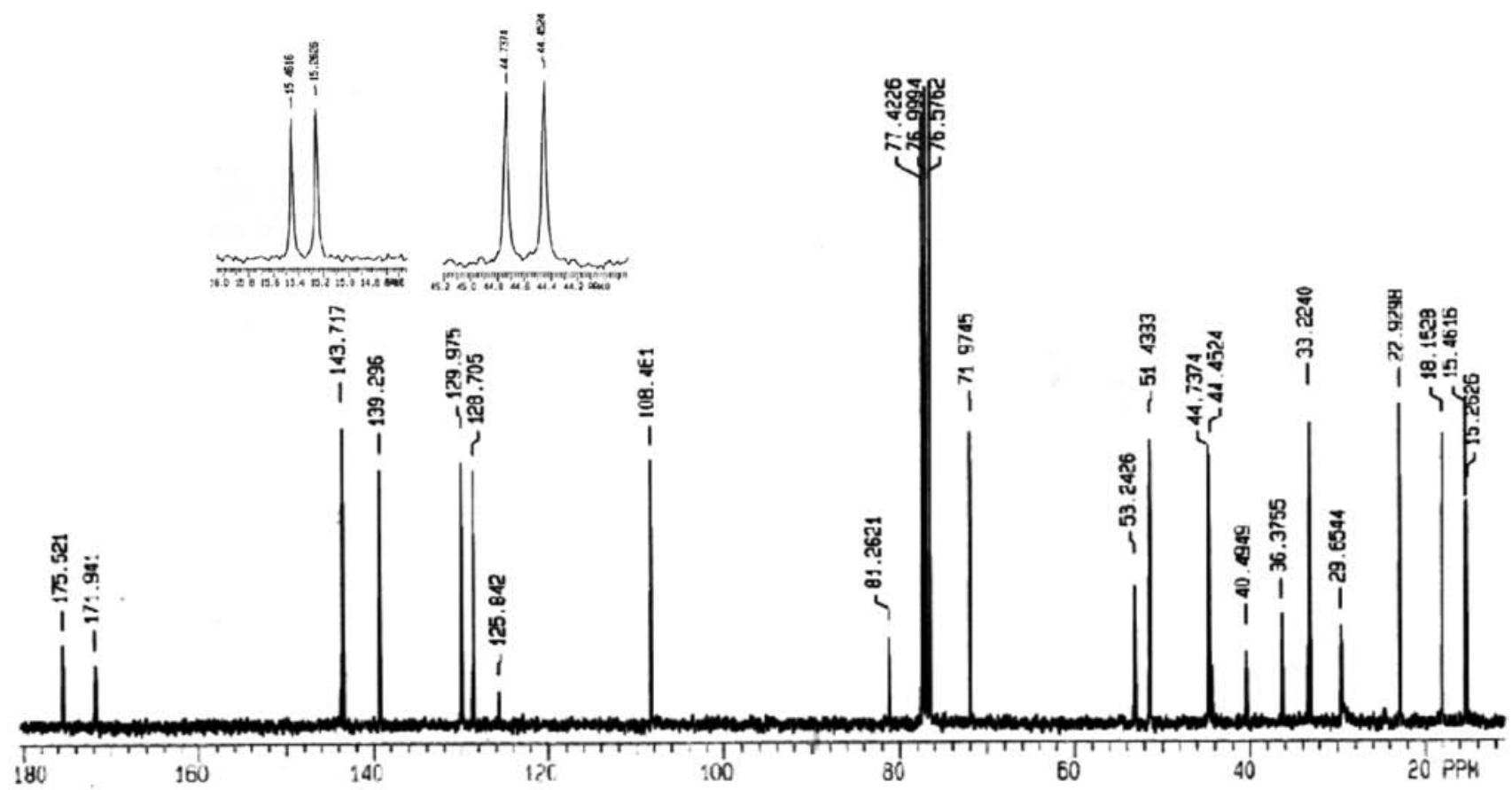

Figure S3. ${ }^{13} \mathrm{C}$ NMR $\left(75.4 \mathrm{MHz}, \mathrm{CDCl}_{3}\right)$ of the new compound 2.

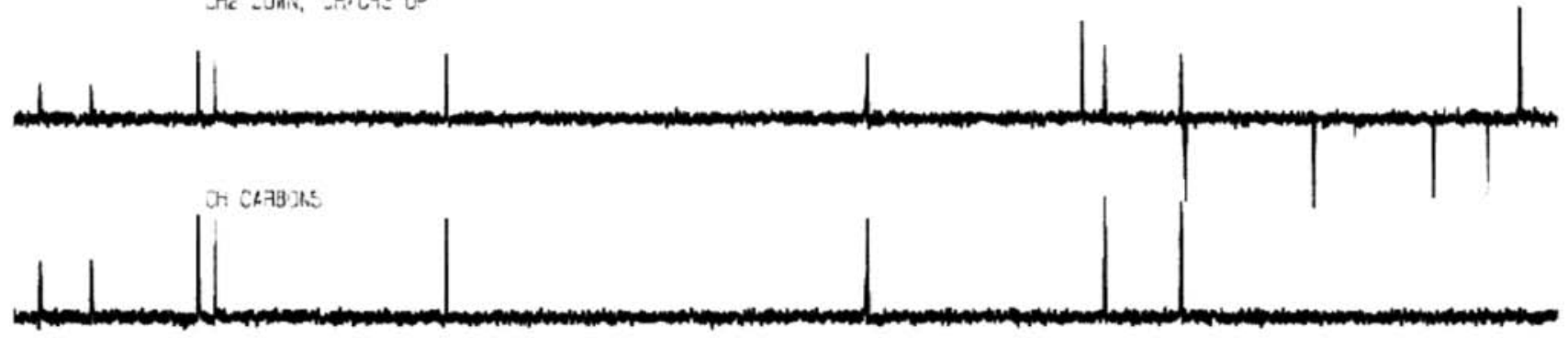

$$
\therefore L L=70^{-} C A M T O D C A R E Z N S
$$

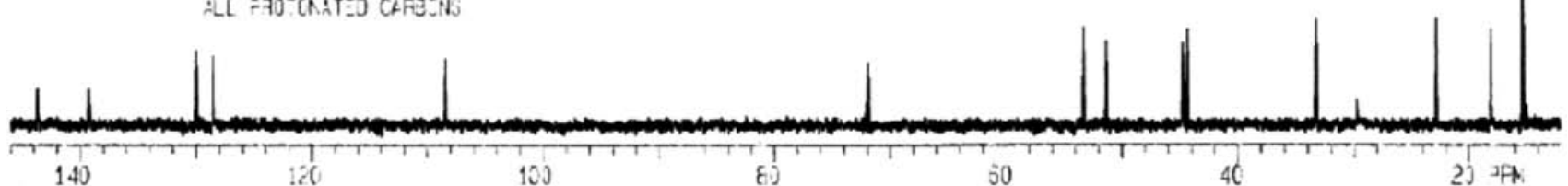

Figure S4. DEPT spectrum of the new compound 2. 


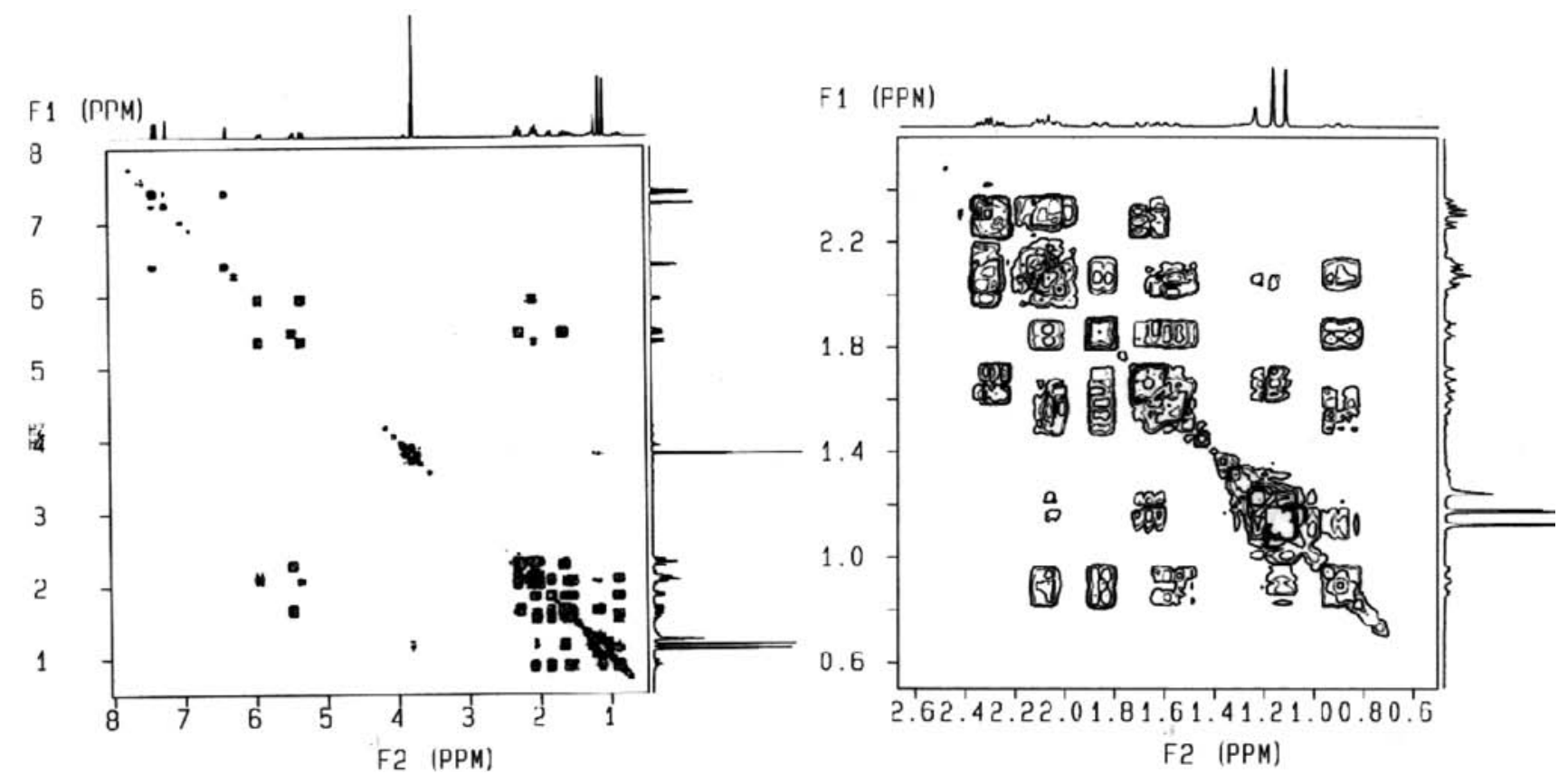

Figure S5. ${ }^{1} \mathrm{H},{ }^{1} \mathrm{H}-\mathrm{COSY}$ spectrum of the new compound 2.

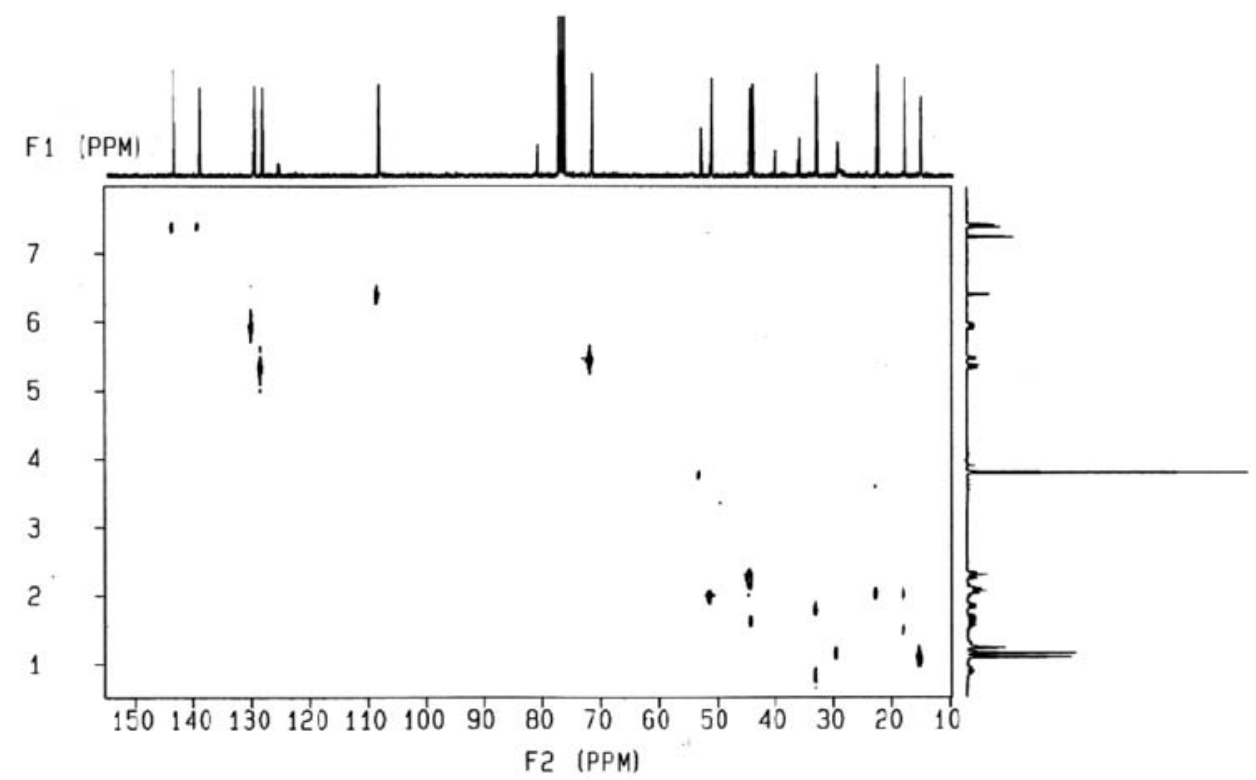

Figure S6. HETCOR spectrum of the new compound 2. 


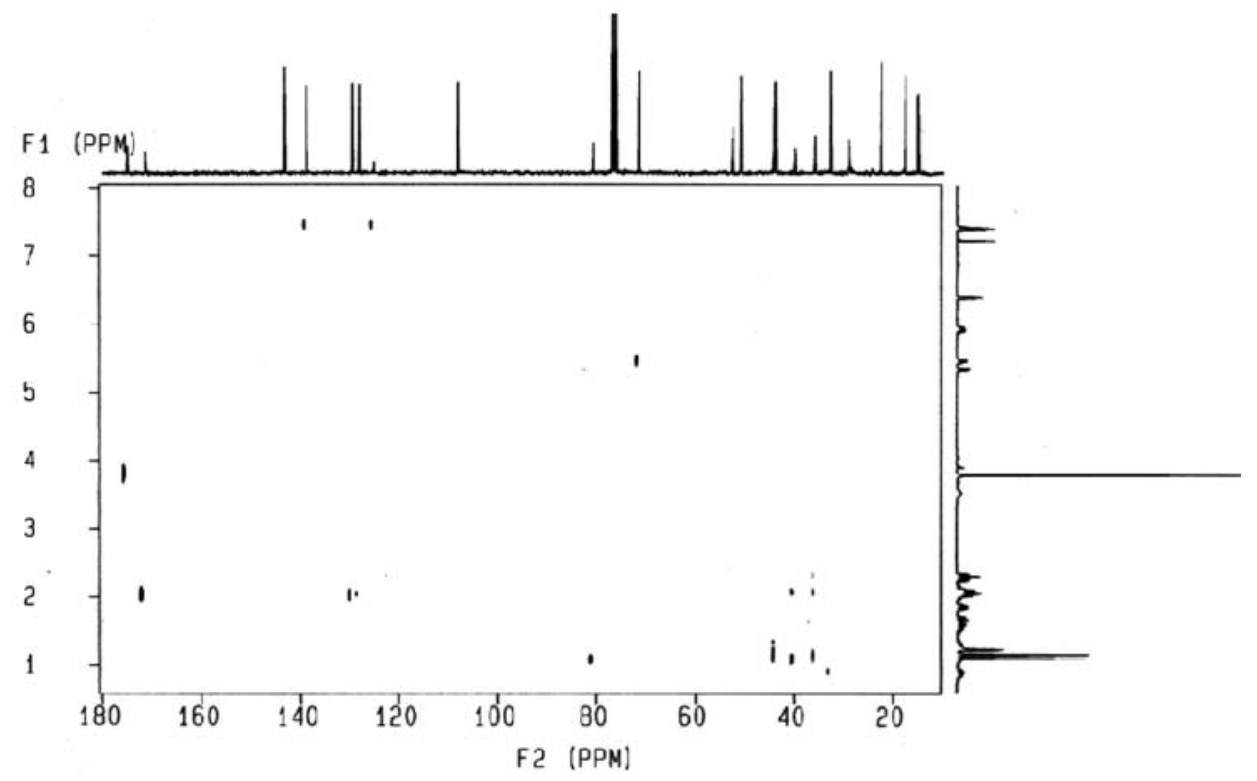

Figure S7. COLOC spectrum of the new compound 2.
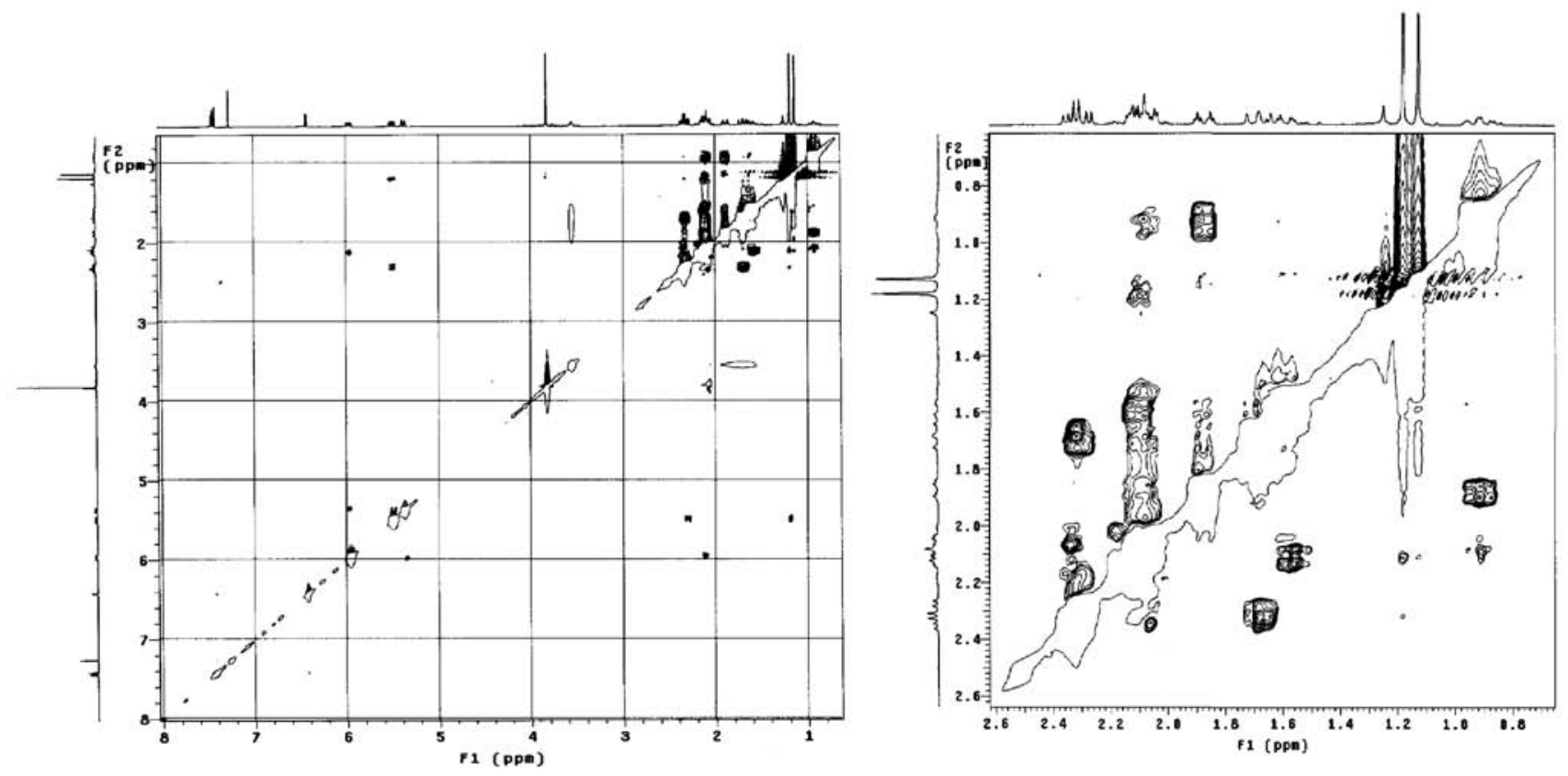

Figure S8. NOESY spectrum of the new compound 2. 

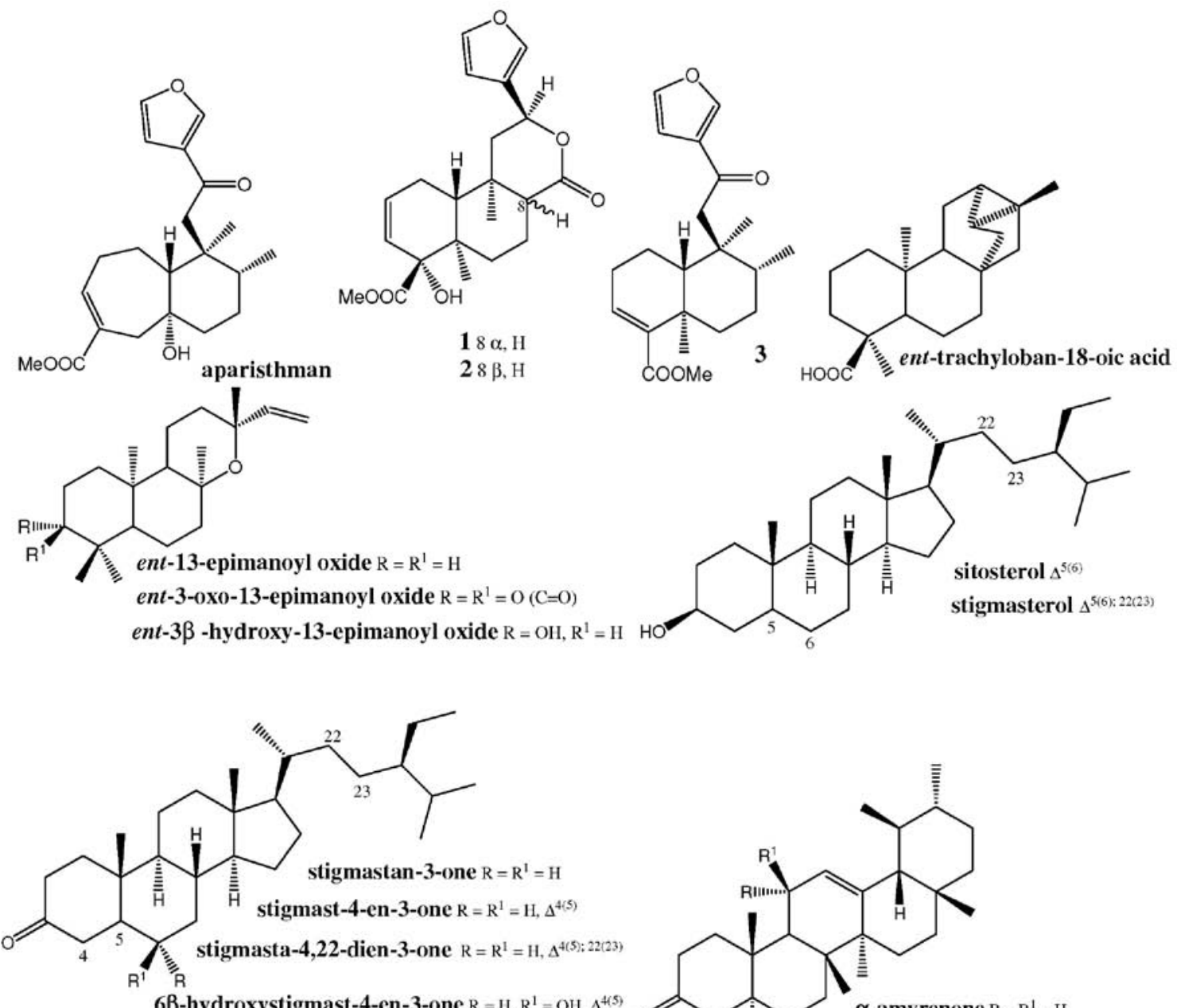

$6 \beta$-hydroxystigmast-4-en-3-one $\mathrm{R}=\mathrm{H}, \mathrm{R}^{1}=\mathrm{OH}, \Delta^{4(5)}$

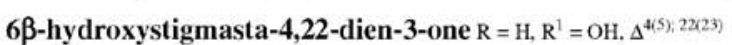
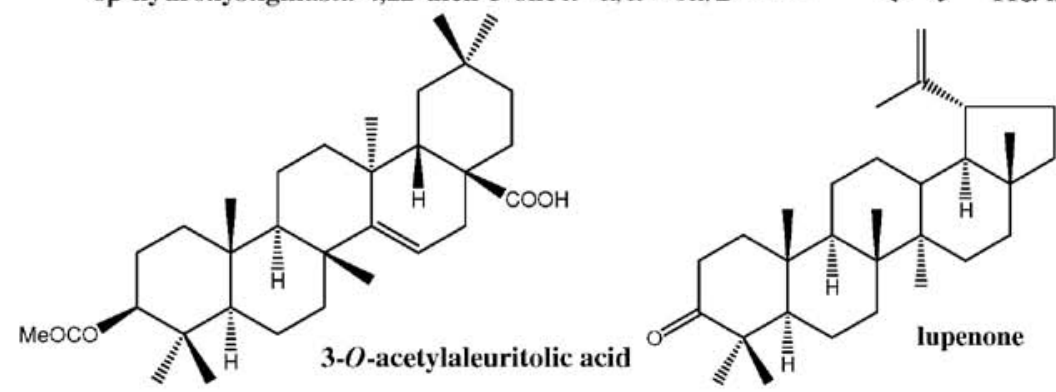

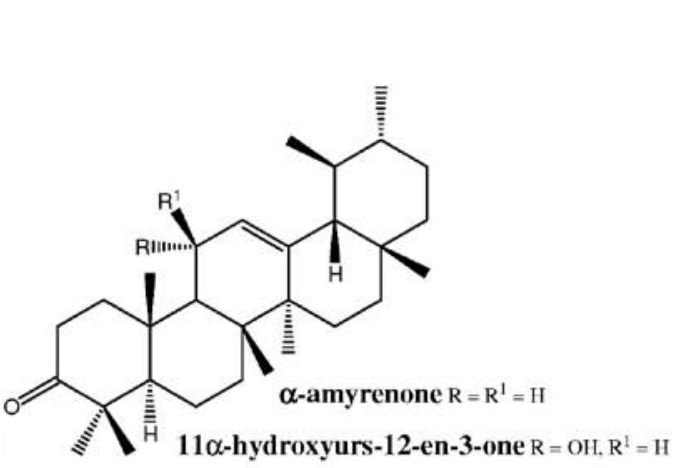

sitosterol $\Delta^{5(6)}$
stigmasterol $\Delta^{5(6): 22(23)}$

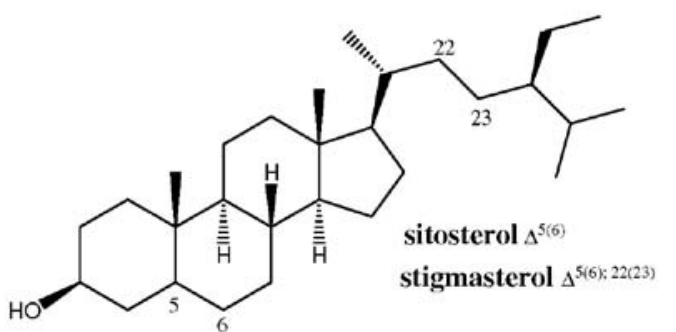

Figure S9. Structures of all identified compounds.

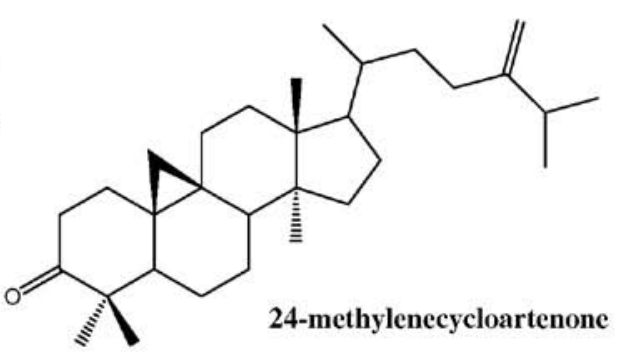

